\title{
An examination of the long-term CO records from MOPITT and IASI: comparison of retrieval methodology
}

\author{
M. George ${ }^{1}$, C. Clerbaux ${ }^{1,2}$, I. Bouarar ${ }^{3}$, P.-F. Coheur ${ }^{2}$, M. N. Deeter ${ }^{4}$, D. P. Edwards ${ }^{4}$, G. Francis ${ }^{4}$, J. C. Gille ${ }^{4}$, \\ J. Hadji-Lazaro ${ }^{1}$, D. Hurtmans ${ }^{2}$, A. Inness ${ }^{5}$, D. $\mathrm{Mao}^{4}$, and H. M. Worden ${ }^{4}$ \\ ${ }^{1}$ Sorbonne Universités, UPMC Univ. Paris 06, Université Versailles St-Quentin, CNRS/INSU, LATMOS-IPSL, Paris, France \\ ${ }^{2}$ Spectroscopie de l'Atmosphère, Chimie Quantique et Photophysique, \\ Université Libre de Bruxelles (U.L.B.), Brussels, Belgium \\ ${ }^{3}$ Max Planck Institute for Meteorology, Hamburg, Germany \\ ${ }^{4}$ Atmospheric Chemistry Observations and Modeling, National Center for Atmospheric Research, Boulder, CO, USA \\ ${ }^{5}$ European Centre for Medium-Range Weather Forecasts, Reading, UK \\ Correspondence to: M. George (maya.george@latmos.ipsl.fr)
}

Received: 12 February 2015 - Published in Atmos. Meas. Tech. Discuss.: 23 April 2015

Revised: 14 August 2015 - Accepted: 8 September 2015 - Published: 15 October 2015

\begin{abstract}
Carbon monoxide (CO) is a key atmospheric compound that can be remotely sensed by satellite on the global scale. Fifteen years of continuous observations are now available from the MOPITT/Terra mission (2000 to present). Another 15 and more years of observations will be provided by the IASI/MetOp instrument series (2007-2023 >). In order to study long-term variability and trends, a homogeneous record is required, which is not straightforward as the retrieved quantities are instrument and processing dependent. The present study aims at evaluating the consistency between the $\mathrm{CO}$ products derived from the MOPITT and IASI missions, both for total columns and vertical profiles, during a 6-year overlap period (2008-2013). The analysis is performed by first comparing the available 2013 versions of the retrieval algorithms (v5T for MOPITT and v20100815 for IASI), and second using a dedicated reprocessing of $\mathrm{MO}$ PITT CO profiles and columns using the same a priori information as the IASI product. MOPITT total columns are generally slightly higher over land (bias ranging from 0 to $13 \%$ ) than IASI data. When IASI and MOPITT data are retrieved with the same a priori constraints, correlation coefficients are slightly improved. Large discrepancies (total column bias over $15 \%$ ) observed in the Northern Hemisphere during the winter months are reduced by a factor of 2 to 2.5 . The detailed analysis of retrieved vertical profiles compared with collocated aircraft data from the MOZAIC-IAGOS network, illustrates the advantages and disadvantages of a con-
\end{abstract}

stant vs. a variable a priori. On one hand, MOPITT agrees better with the aircraft profiles for observations with persisting high levels of $\mathrm{CO}$ throughout the year due to pollution or seasonal fire activity (because the climatology-based a priori is supposed to be closer to the real atmospheric state). On the other hand, IASI performs better when unexpected events leading to high levels of $\mathrm{CO}$ occur, due to a larger variability associated with the a priori.

\section{Introduction}

Measuring the variability and trends in carbon monoxide (CO) on the global scale is essential as it is an ozone and carbon dioxide precursor, and it regulates the oxidizing capacity of the troposphere through its destruction cycle involving the hydroxyl radical (OH) (Duncan and Logan, 2008). The background $\mathrm{CO}$ atmospheric loading varies as a function of season and latitude and is significantly perturbed by human activities related to combustion processes: car traffic, heating/cooking systems, industrial activities, etc. $\mathrm{CO}$ accumulates in the Northern Hemisphere $(\mathrm{NH})$ during the winter months due to low solar insolation corresponding to less chemical destruction, and concentrations peak in early spring each year. Natural and human-induced fires also affect the $\mathrm{CO}$ budget, in particular in boreal areas where intense fires occur during the dry season and in the tropics where large 
emissions are linked to agricultural practices (Edwards et al., 2006). CO emissions inventories still present large uncertainties (Streets et al., 2013), and separating anthropogenic and biomass burning contributions is essential for attributing $\mathrm{CO}$ long-term trends (Strode and Pawson, 2013).

Due to its moderate lifetime (1-3 months), $\mathrm{CO}$ is an excellent tracer of tropospheric pollution, which can often travel far downwind, even between continents (HTAP, 2010). CO can easily be measured by infrared remote sensing as it combines high variability and significant perturbations over background concentration levels with a strong infrared absorption signature. Over the last 2 decades, Earth-observing satellites have revolutionized our ability to map $\mathrm{CO}$ and to understand its evolving concentration on regional and global scales. At the moment several satellite missions using the thermal infrared (TIR) spectral range to sound the atmosphere are delivering CO data, including MOPITT on EOS/Terra launched at the end of 1999 (Drummond and Mand, 1996; Deeter et al., 2003), AIRS on the EOS/Aqua satellite launched in 2002 (Aumann et al., 2003; McMillan et al., 2005), TES on the EOS/Aura satellite launched in 2003 (Beer, 2006; Rinsland et al., 2006), and IASI on the EPS/MetOp-A satellite launched in 2006 (Clerbaux et al., 2009; George et al., 2009). All these missions are maturing and have exceeded their foreseen lifetimes. More recently, the CrIS (Gambacorta et al., 2014) and IASI/MetOp-B instruments were launched onboard the SNPP and MetOp-B satellites, in 2011 and 2012, respectively.

Each of these thermal infrared sensors has a dedicated CO retrieval algorithm that was improved over time and has benefited from cross comparisons with other products. The optimal estimation (OE) retrieval approach (Rodgers, 2000) is a widely used inverse method in atmospheric sciences to derive geophysical products from instrument measurements (e.g., radiances). It regularizes the under-determined inverse problem and provides the best estimates given the observations and some prior knowledge of the atmospheric state. For MOPITT and IASI, one CO vertical profile and its associated integrated total column are retrieved at each sounding location and the OE provides useful diagnostic variables such as the averaging kernel matrix (the sensitivity of both the instrument and the retrieval to the abundance of $\mathrm{CO}$ at different altitudes), the degrees of freedom for signal (DOFS, information content of the retrieval, given by the trace of the averaging kernel matrix) and the posterior error covariance matrix. The latter includes the contributions from the limited vertical sensitivity (smoothing error), from the instrumental noise, and from uncertainties to all other parameters included in the forward model (temperature profile, surface emissivity, interfering gases, spectroscopy, etc.). The retrieved CO profile can be expressed as a linear combination of the true atmospheric profile and the a priori profile, weighted by the averaging kernel matrix, plus contributions from errors associated with both the observation and the other parameters (see Rodgers (2000) for more details). A key element of the retrieval process is the choice of the a priori, which consists of an expected profile $\left(x_{a}\right)$ and its associated variancecovariance matrix $\left(\mathbf{S}_{a}\right)$, to constrain the retrieved CO profile to fall within the range of physically realistic solutions (based on the known variability of this species).

Previous studies have inter-compared $\mathrm{CO}$ retrieved columns or profiles over specific areas and limited time periods. Clerbaux et al. (2002) made a first comparison of the TES, MOPITT, and IASI retrieval algorithms to retrieve CO columns from a common nadir radiance data set, provided by the IMG/ADEOS thermal infrared instrument. Luo et al. (2007) compared, for 2 days in September 2004, TESretrieved $\mathrm{CO}$ profiles adjusted to the MOPITT a priori with the MOPITT retrievals and also the adjusted TES CO profiles with the MOPITT profiles vertically smoothed by the TES averaging kernels. Warner et al. (2007) used the MOPITT a priori profile as AIRS first guess and showed global improvements to the agreements between $\mathrm{CO}$ at $500 \mathrm{hPa}$ from these two instruments, for the 2-month time period of the INTEX-A campaign. Ho et al. (2009) applied TES a priori profiles and covariance matrix to a modified MOPITT retrieval algorithm, for a 1-month study. George et al. (2009) compared the IASI CO columns with MOPITT, AIRS and TES CO columns, adjusted with the IASI a priori assumptions, for three different months (August 2008, November 2008 and February 2009) and on the global scale. Illingworth et al. (2011) compared IASI CO with MOPITT CO data over a localized region of Africa, for 1 day. They first retrieved the MOPITT profiles using IASI a priori assumptions and then applied the averaging kernels resulting from these new MOPITT retrievals to the IASI CO profiles. Finally, Worden et al. (2013) examined hemispheric and regional trends for CO from all four missions, from 2000 through 2011.

The present study compares the CO record from MOPITT and IASI on the global scale, in order to setup a framework for building a consistent long-term data set. These two sensors together already provided a 15 -year record of data, including 6 years of common observation (2008-2013). The analysis is performed on both retrieved total columns and vertical profiles, and focuses on identifying differences in the retrievals due to a priori assumptions. Extended comparison is performed at several locations, over the 6-year overlap period, representative of diverse geophysical situations. Section 2 describes the MOPITT and IASI instrument characteristics, as well as the current retrieval algorithms and $\mathrm{CO}$ products. Section 3 compares the total columns for the 20082013 period, first using each retrieval algorithm, and then using the IASI a priori information to constrain the MOPITT retrievals. Section 4 details how the a priori assumptions impact the profile shape. A comparison with aircraft $\mathrm{CO}$ measurements from the IAGOS program is also presented. Section 5 concludes the paper and provides perspectives for the future. 


\section{MOPITT and IASI data}

\subsection{The instruments}

\subsubsection{Orbit, geometry and absorption spectral range}

MOPITT and IASI are both sun-synchronous polar-orbiting missions designed to measure the spectral radiance at the top of the atmosphere, in the infrared spectral range, using a nadir viewing geometry. IASI and MOPITT cross the equator at around 09:30 and 10:30 LT respectively, each morning and evening. To retrieve $\mathrm{CO}$ they take advantage of absorption in the fundamental 1-0 CO rotation-vibration band centered around $4.7 \mu \mathrm{m}$. Note that MOPITT also has the ability to measure the 2-0 overtone at $2.3 \mu \mathrm{m}$ (Deeter et al., 2013). For consistency only the products derived from the inversion in the thermal infrared is compared in this paper.

\subsubsection{Measurement technique}

The MOPITT and IASI measurement techniques differ. MOPITT uses gas filter correlation radiometry where the signal passes through cells containing gaseous $\mathrm{CO}$ in the instrument. These act as a high spectral resolution filter, matching the signature of the atmospheric gas. The transmission through the gas cells is modulated by varying either cell pressure (PMC) or cell length (LMC) to create signals corresponding to high and low cell gas optical depth. These signals are then averaged (A-signals) or differenced (D-signals) for use in the retrieval of CO profiles (Edwards et al., 1999; Drummond et al., 2010). The D-signal is only significant at the target gas absorption line frequencies, thus providing high spectral resolution information on $\mathrm{CO}$ abundance, while the A-signal provides information on the underlying scene such as surface temperature and emissivity. The two thermal infrared channels on MOPITT use PMC and LMC gas cells at different pressures to provide sensitivity to the pressurebroadened absorption of $\mathrm{CO}$ at different altitudes in the troposphere.

IASI is a Fourier Transform Spectrometer with a spectral coverage extending from 15.5 to $3.62 \mu \mathrm{m}$ (645 to $2760 \mathrm{~cm}^{-1}$ ), associated with an imaging instrument. The spectrometer part of the instrument is based on a Michelson interferometer, and the optical part consists of a cold box subsystem cooled to a temperature of $94 \mathrm{~K}$ that provides measurements in three spectral bands with different photo-detectors; hot optics elements which form the heart of the interferometer; and a black body subsystem for calibration views. The raw measurements performed by IASI are interferograms, which have to be processed to get radiances. To reduce the IASI transmission rate raw interferograms are transformed into radiometrically calibrated spectra before transmission to the ground. The maximum optical path difference is $\pm 2 \mathrm{~cm}$ which leads to $0.5 \mathrm{~cm}^{-1}$ full width at half-maximum resolution (apodized). The radiomet- ric noise below $2250 \mathrm{~cm}^{-1}$ ranges between 0.1 and $0.3 \mathrm{~K}$ for a reference blackbody at $280 \mathrm{~K}$.

\subsubsection{Horizontal sampling and vertical sensitivity}

MOPITT observations are made with a four-pixel linear detector array which scans across the satellite track forming a $650 \mathrm{~km}$-wide swath. At nadir, the footprint of each pixel is approximately $22 \mathrm{~km}$ by $22 \mathrm{~km}$. Each cross-track scan is composed of 116 pixels. It produces nearly continuous coverage within that swath as the satellite flies. IASI views the ground through a cross-track rotary scan mirror which provides $\pm 48.3^{\circ}$ ground coverage along the swath with views towards on board calibration sources every scan cycle during $8 \mathrm{~s}$. The along track drift is compensated during the acquisition of each measurement. A total of 120 views are collected over a swath of $\sim 2200 \mathrm{~km}$ (30 arrays of 4 individual elliptical pixels - each of which of $12 \mathrm{~km}$ diameter at nadir, increasing at the larger viewing angles). Figure 1 illustrates 1-day/morning overpasses of typical CO total column maps measured by IASI and MOPITT in April 2013. For MOPITT the Earth's surface is mostly covered in about 3 days. For IASI a global coverage is achieved twice a day, with some gaps between orbits around the equator. The two instruments are able to measure day and night, but clouds in the field of view can obstruct or reduce the visibility and prevent observation of the lower layers of the atmosphere.

$\mathrm{CO}$ is retrieved at each location with a specific vertical sensitivity (characterizing the part of the atmosphere that is sounded), which is a function of wavenumbers (position and shapes of absorption lines), the overlaps with other absorbing species, the concentration profile of the species, the local surface temperature/emissivity, the temperature profile, and the instrumental specifications (noise and spectral resolution). For CO sensing in the TIR, the information is in the majority of the cases coming from the mid troposphere, as can be seen from the averaging kernels represented in Fig. 1. A key variable affecting sensitivity is temperature, with hotter surface providing generally a stronger signal relative to instrument and geophysical noise and thus allowing retrieval of $\mathrm{CO}$ with a higher accuracy. Another important parameter for sounding the lower part of the atmosphere is thermal contrast, which is the temperature difference between the surface and the near-surface atmosphere, which determines the instrument sensitivity to the boundary layer (Deeter et al., 2007; Clerbaux et al., 2008). Note that bright land surfaces, such as ice and desert sand, sometimes lead to poor retrievals, because of insufficiently detailed knowledge of the surface emissivity and reflectivity (in the $\mathrm{CO}$ spectral range, solar radiation is not negligible).

\subsection{Retrieved CO products}

The MOPITT and IASI missions have now accumulated 15 and 7 years respectively of near-continuous global data for 

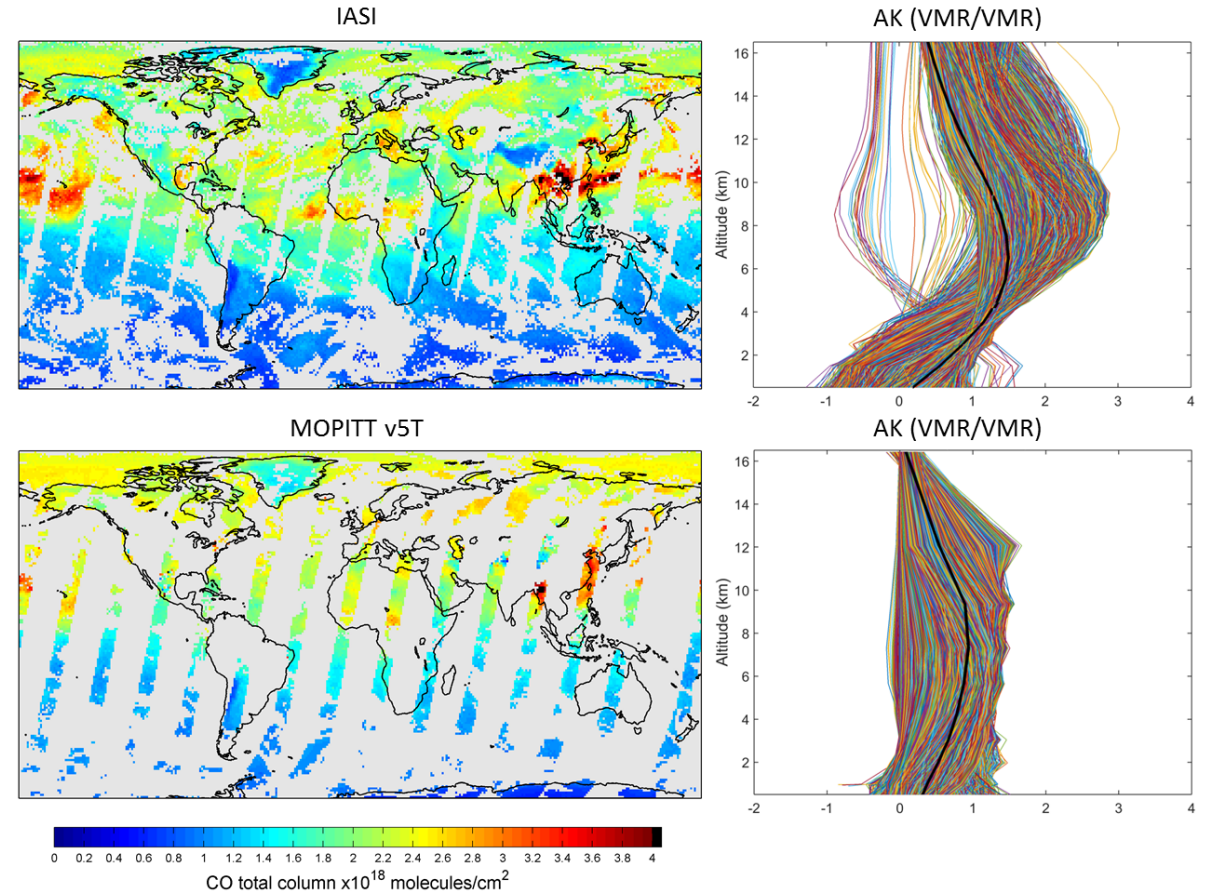

Figure 1. CO total column global distributions (left) for 15 April 2013 (morning overpass) and the associated averaging kernels (right), for IASI (top) and MOPITT (bottom). The mean averaging kernel function is represented in black.

tropospheric CO. For this comparison we used the retrieval algorithm versions that were running in 2013 (MOPITT v5T and IASI FORLI v20100815) and the retrieved CO profile products, from which integrated total columns are derived, along with their associated averaging kernel matrices (for profiles) or vector (for columns). Only the data from the IASI/MetOp-A mission are analyzed here.

Table 1 provides a detailed description of the retrieved products, the a priori information, and the auxiliary data (temperature, emissivity, cloud content) for each mission. Note that the number of retrieved layers exceeds the number of independent pieces of information available vertically and hence is not representative of the vertical resolution of the observation.

Previous validation studies using ground-based, aircraft and satellite data have shown that CO total columns from MOPITT and IASI are retrieved with an error generally below $10-15 \%$ at mid and tropical latitudes, but can have larger errors in polar regions (MOPITT: Deeter et al., 2012, 2013; Emmons et al., 2004, 2009; IASI: George et al., 2009; Pommier et al., 2010; De Wachter et al., 2012; Kerzenmacher et al., 2012). The profiles are only weakly resolved, with $<1$ to $\sim 2.5$ independent pieces of information, depending mostly on the thermal state of the atmosphere. A DOFS of less than 1 indicates that the a priori information dominates the calculated total column, whereas a DOFS of 2 or more means that at least two independent partial columns can be retrieved. The highest sensitivity is achieved in the inter- tropical region or at mid-latitudes during daytime and over land: for instance, there is a gain of 0.5 DOFS above the northern mid-latitude continental surfaces between the morning and evening orbits (Hurtmans et al., 2012).

A major difference between MOPITT and IASI retrievals resides in the choice of the a priori, which is fixed for IASI, and variable for MOPITT. Having a variable or a static a priori has implications on the retrieved data set, with both choices presenting advantages and disadvantages as discussed hereafter. Figure 2 represents the a priori profile(s) and the variance-covariance matrices $\left(\mathbf{S}_{a}\right)$, for MOPITT (in September 2010) and for IASI (invariant). These were built using chemistry-transport model simulations and other available data. For MOPITT v5T the a priori profile varies as a function of location and time of year and it is based on a monthly climatology of the MOZART-4 chemistry transport model. For each retrieval, the climatology is spatially and temporally interpolated to match the date and location of the observation. The fixed $\mathbf{S}_{a}$ matrix allows for a $30 \%$ variability in each retrieved layer. The off-diagonal elements which define the correlations between the different layers are consistent with a short vertical correlation length which limits the spread of information from one layer to another (Deeter et al., 2010). On the contrary, the IASI a priori consists on a single profile, and a fixed $\mathbf{S}_{a}$ matrix, built from a climatology that uses LMDz-INCA model outputs, MOZAIC aircraft data and ACE-FTS satellite profiles (Turquety et al., 2009). The a priori profile is around $90 \pm 20 \mathrm{ppbv}$ from the surface 
Table 1. Description of the MOPITT and IASI retrieved products.

\begin{tabular}{|c|c|c|}
\hline & MOPITT & IASI \\
\hline \multicolumn{3}{|l|}{$\mathrm{CO}$ profile product } \\
\hline Algorithm version & MOPFAS v5.T (TIR obs.) & FORLI v20100815 \\
\hline Retrieved layers & $\begin{array}{l}\text { 10-level grid (surface, } 900,800,700,600,500,400,300,200 \text {, and } \\
100 \mathrm{hPa} \text { ) }\end{array}$ & $\begin{array}{l}181 \mathrm{~km} \text { thick layers, with an additional layer from } \\
18 \mathrm{~km} \text { to the top-of-atmosphere (TOA) }\end{array}$ \\
\hline Units & $\log \left(\mathrm{VMR}^{*}\right)$ & Partial columns, constant within each layer \\
\hline Reference & Deeter et al. (2013) & Hurtmans et al. (2012) \\
\hline \multicolumn{3}{|l|}{ A priori information } \\
\hline A priori profile & $\begin{array}{l}\text { Variable a priori profile (lat, lon, month) based on 1-degree spatially } \\
\text { interpolated climatology (MOZART-4 model simulations) }\end{array}$ & $\begin{array}{l}\text { Invariant, mean of the ensemble of profiles used to } \\
\text { build } \mathbf{S}_{a}\end{array}$ \\
\hline A priori var-cov matrix & $\begin{array}{l}\text { Invariant fractional VMR variability of } 30 \% \text { with vertical correla- } \\
\text { tion over } 100 \mathrm{hPa} \text { scale heights } \\
\left(C_{i j}=C_{0} \exp \left[-\left(p_{i}-p_{j}\right)^{2} / P_{c}^{2}\right] \text { where } C_{0}=(0.30 \log 10 e)^{2} \text { and }\right. \\
\left.P_{c}=100 \mathrm{hPa}\right)\end{array}$ & $\begin{array}{l}\text { Variance-covariance matrix based on MOZAIC } \\
\text { aircraft data + satellite data (ACE-FTS) + LMDz- } \\
\text { INCA model simulations }\end{array}$ \\
\hline Correlation length & $100 \mathrm{hPa}$ & Variable; about $5 \mathrm{~km}$ \\
\hline Reference & Deeter et al. (2010) & Turquety et al. (2009) \\
\hline & & Hurtmans et al. (2012) \\
\hline \multicolumn{3}{|l|}{ Auxiliary information } \\
\hline Cloud information & MODIS cloud mask + MOPITT thermal channel radiances & $\begin{array}{l}\text { AMSU-A/AVHRR data + IASI radiances, from the } \\
\text { L2 IASI operational product }\end{array}$ \\
\hline Cloud allowance & $<5 \%$ & $<25 \%$ \\
\hline Temperature profile & Interpolating reanalysis profiles from NCEP (fixed) & L2 IASI operational product (fixed) \\
\hline Surface Temperature & Interpolated surface air temperatures from NCEP (adjusted) & L2 IASI operational product (adjusted) \\
\hline Emissivity & $\begin{array}{l}\text { Analysis of MOPITT radiances and corresponding MODIS surface } \\
\text { temperatures (adjusted) }\end{array}$ & Zhou et al. (2011) climatology (fixed) \\
\hline $\mathrm{H}_{2} \mathrm{O}$ content & Interpolating reanalysis profiles from NCEP (fixed) & L2 IASI operational product (adjusted) \\
\hline \multicolumn{3}{|l|}{ Data availability } \\
\hline Data available from & https://eosweb.larc.nasa.gov/HPDOCS/datapool/ & http://www.pole-ether.fr/ \\
\hline
\end{tabular}

$* \mathrm{VMR}=$ Volume Mixing Ratio.
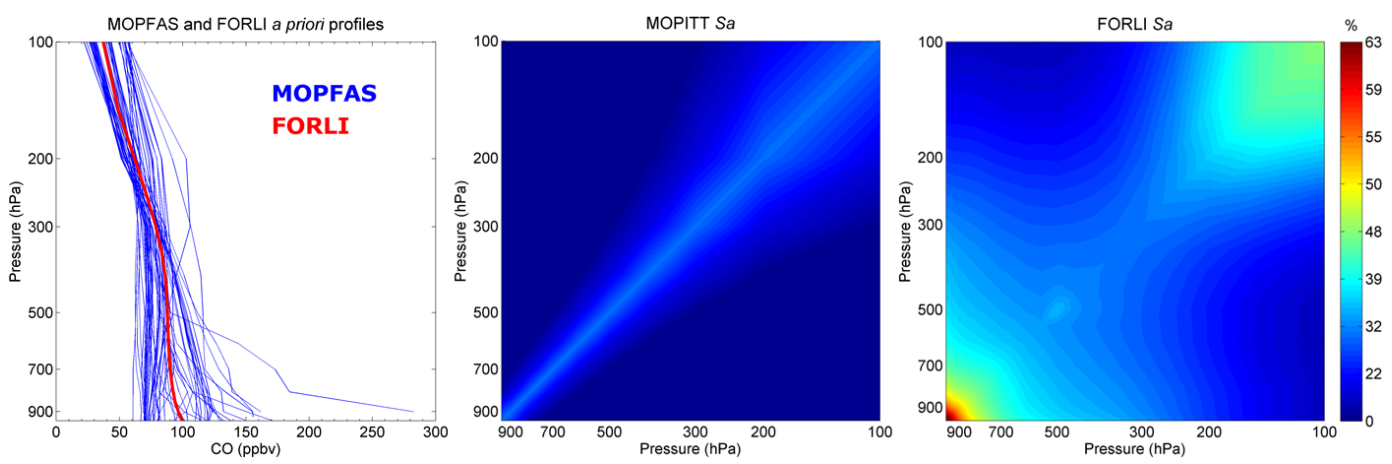

Figure 2. (Left panel) Single a priori profile used by FORLI (in red) and a selection of MOPITT a priori profiles (in blue). The MOPITT profiles were picked over the globe in September 2010, one profile per $18^{\circ}$ latitude $\times 60^{\circ}$ longitude box. (Middle panel) a priori variancecovariance matrix $\left(\mathbf{S}_{a}\right)$ used by MOPFAS. (Right panel) a priori variance-covariance matrix $\left(\mathbf{S}_{a}\right)$ used by FORLI.

to the middle troposphere, and then smoothly decreases to $40 \mathrm{ppbv}$ from $7 \mathrm{~km}$ up to $18 \mathrm{~km}$. The $\mathbf{S}_{a}$ matrix allows a maximum variability in the first layer $(63 \%)$, decreases to $35 \%$ between 5 and $6 \mathrm{~km}$, to $30 \%$ (as MOPITT) between 6 and $10 \mathrm{~km}$, and is increasing again, reaching $45 \%$ between 15 and $16 \mathrm{~km}$ (see Fig. 2). Off diagonal elements are calculated from the ensemble profiles, and allow the information to be projected from layers with high sensitivity to layers where the sensitivity is much weaker. The correlation length, therefore variable, is about $5 \mathrm{~km}$. 


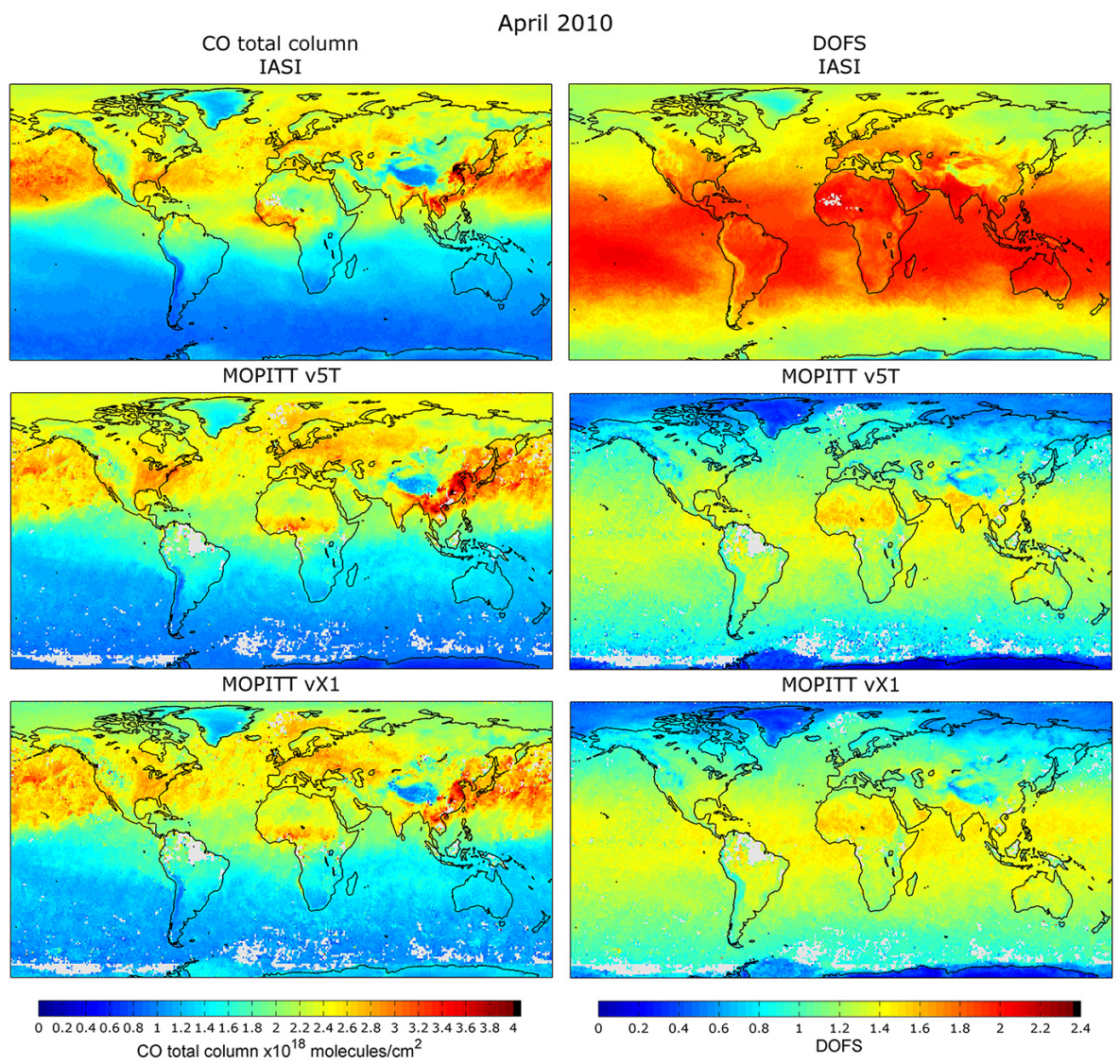

Figure 3. (Top panel) CO total column and DOFS distributions for April 2010, for IASI, (middle panel) MOPITT v5T and (bottom panel) MOPITT vX1. Day time data are averaged over a $1^{\circ} \times 1^{\circ}$ grid.

\section{Comparison of CO total column products for selected periods and regions}

\subsection{Global scale comparison}

The comparison analysis is performed over the period extending from January 2008 to December 2013, a period when MOPITT and IASI were both in operation. As the two instruments are not onboard the same platform, neither the measurement time nor the location are exactly the same.

The top and middle panels of Fig. 3 show the monthly average for $\mathrm{CO}$ total column distribution (daytime data) for April 2010 along with the monthly average of the DOFS for the profile retrieval, for each instrument. As expected, it can be seen that large concentrations of $\mathrm{CO}$ are found near emission sources, and plumes are transported downwind. In the $\mathrm{NH}$ elevated levels of $\mathrm{CO}$ are found above the west and east coasts of the USA, over Europe, and over East Asia. Due to long range transport, high $\mathrm{CO}$ concentrations are also observed over the Northern Pacific and Atlantic oceans. In the tropics, elevated $\mathrm{CO}$ concentrations are found over the Guinea gulf countries (fires). Note that reduced CO total columns at the location of mountains in North and South America, as well as in the Himalayas, are due to surface height. Figure 4 provides in addition a time series of zonal mean total column $\mathrm{CO}$ over the entire period. $\mathrm{NH}$ concentrations peak in April, after accumulating during winter, and drop off gradually until late summer as the increasing solar insolation activates tropospheric chemistry (except over Siberia and Alaska fire regions where CO concentrations increase in summer). In the tropics the $\mathrm{CO}$ maximum is mainly associated with fires occurring in the Amazon basin, in central and southern Africa and sometimes over Australia, with maximum in August-November. Major fires occurring in Russia in August 2010 (Yurganov et al., 2011; Krol et al., 2013; R'Honi et al., 2013) and in Siberia in July 2012 (Ponomarev, 2013) are also visible on the zonal mean total column plots. The associated DOFS distributions (right panels of Fig. 3) illustrate the strong latitudinal variations due to temperature changes. The patterns look similar, but MOPITT is showing lower associated DOFS than IASI. Note that as the instruments are intrinsically different we do not expect their DOFS values to be the same, and that both the a priori and the measurement covariance matrix $\left(\mathbf{S}_{e}\right)$ will impact the DOFS values. 


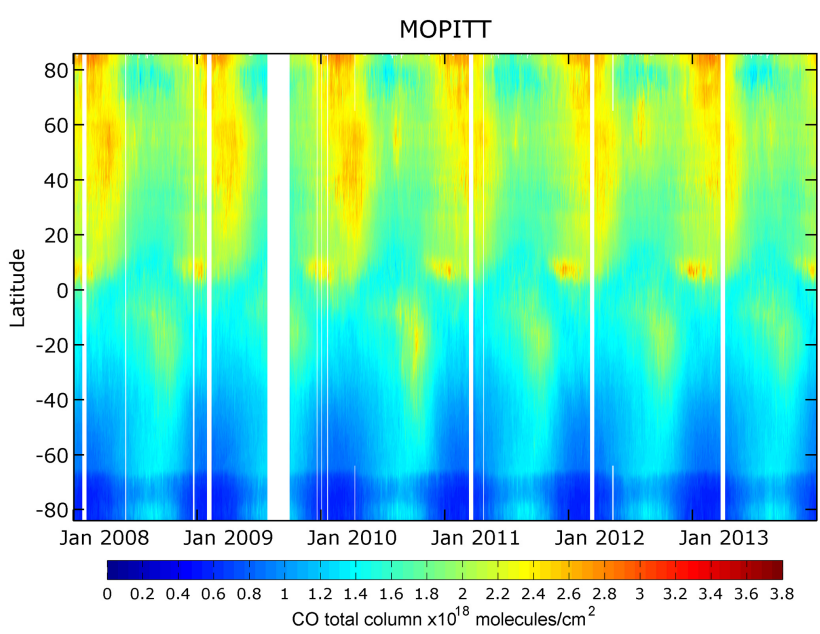

IASI

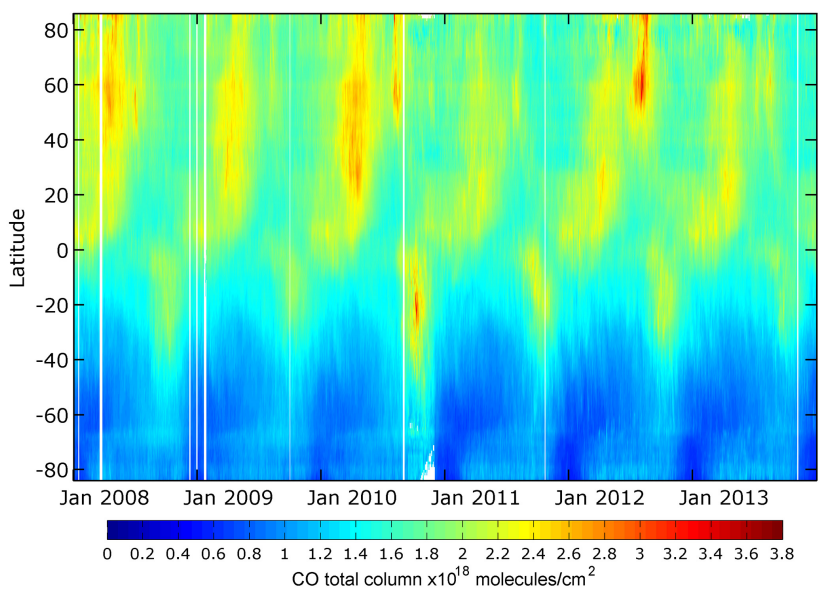

Figure 4. (Top panel) Daily zonal mean total column CO for MOPITT (v5T) and (bottom panel) IASI, from 2008 to 2013. White strips correspond to days with no data (i.e., no MOPITT data between 28 July and 29 September 2009, due to a cooler failure; or annually-scheduled MOPITT hot calibration/decontamination procedures).

Even if the general horizontal spatial concentration patterns agree well, differences in the $\mathrm{CO}$ total columns can be seen when comparing the MOPITT and IASI data for the same areas/periods. In Fig. 5a representing the relative differences between IASI and MOPITT v5T for 1-month (April 2010), more than $70 \%$ of the plotted data do not exceed $10 \%$ (ratio calculated from the original grid), which is the $\mathrm{CO}$ accuracy specification for both missions (Pan et al., 1995; IASI Science Plan, 1998). Note that here we discuss the agreement between the two products, not the absolute accuracy which was evaluated in previous validation papers (e.g., see references provided in Sect. 2.2). MOPITT concentrations are generally larger than the IASI concentrations over land, in particular close to the location of strong emission sources (USA's east coast, China). In contrast, IASI concentrations are generally larger over the ocean, between $30^{\circ} \mathrm{S}$ and $45^{\circ} \mathrm{N}$, and above $75^{\circ} \mathrm{N}$. Major fire events such as in Russia and Siberia (in 2010 and 2012, respectively) appear to be more marked in the IASI data, and likewise for the fires occurring in Africa and Amazonia (Fig. 4). Note that over Antarctica, MOPITT DOFS are close to zero, indicating that the retrieved profile is close to the a priori profile.

It is the aim of this paper to investigate the possible sources of the differences between IASI and MOPITT data measured at the same location. We expect differences to be associated with (i) the different vertical sensitivity of the two sensors, (ii) with the a priori assumptions, (iii) the auxiliary data (e.g., surface temperature, temperature profiles, emissivity, cloud information, etc.) used in the retrieval process, as well as (iv) due to the different air masses sounded (different sounding angles, and between one and 2-hours time lag for the observation time). Because the two instruments fly on different satellites, and rely on different auxiliary data sets (temperature, clouds, etc.), only the differences associated with the a priori assumptions are studied in this paper.

\subsection{Impact of the change of the a priori at global scale}

To study the impact of a change of a priori on the retrieval we made a two-step comparison: first with the native retrieved data, and second with a dedicated retrieval chain set-up at the National Center for Atmospheric Research (NCAR), where the MOPITT data were reprocessed using the IASI a priori profile and $\mathbf{S}_{a}$ matrix (hereafter referred to as MOPITT vX1). It is not possible to exactly convert the IASI $\mathbf{S}_{a}$ matrix (expressed in altitude and partial columns) into a MOPITT-compatible matrix (expressed in pressure levels and $\log (\mathrm{VMR}))$ since the IASI and MOPITT retrieval algorithms exploit mathematically inconsistent formats to express the vertical distribution of CO molecules. Schemes for interpolating or extrapolating $\mathbf{S}_{a}$ may also violate basic properties of covariance matrices, such as positive definiteness. Therefore we built a new a priori profile and covariance matrix from the original profiles ensemble used for the $\mathbf{S}_{a}$ matrix generation in FORLI, on a common 35-pressure-layer grid (The MOPITT algorithm uses a priori information on a 35-level pressure grid to produce 10-level a priori profiles used in the actual retrieval algorithm).

The CO total column distribution measured by MOPITT in April 2010 and reprocessed with the IASI a priori constraints (MOPITT vX1) is shown in Fig. 3 (bottom part). Figure 5 provides the relative difference plots between IASI and MOPITT v5T, MOPITT v5T and MOPITT vX1, as well as between IASI and MOPITT vX1. Probability density functions by latitude bands are also represented (see Fig. $5 \mathrm{~d}-\mathrm{m}$ ). It can be seen that the larger differences between the MOPITT v5T and $\mathrm{vX} 1$ concentrations are observed over the polar regions, where the v5T concentrations are larger than the $\mathrm{vX} 1$ ones at the North Pole $\left(15 \%\right.$ on average between 60 and $\left.90^{\circ} \mathrm{N}\right)$ and smaller over Antarctica ( $-60 \%$ on average between 60 and $90^{\circ} \mathrm{S}$ ). Between $60^{\circ} \mathrm{S}$ and $60^{\circ} \mathrm{N}$, the differences gen- 
(a) 201004 100*(IASI-MOPv5T)/IASI

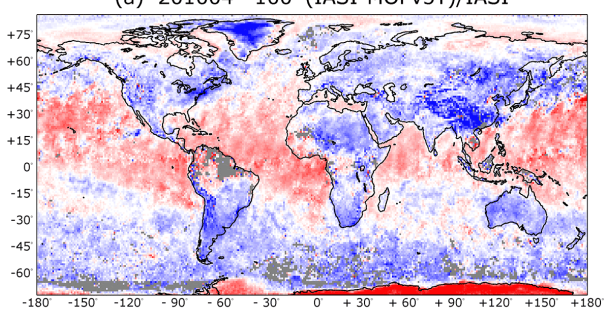

(b) $201004100 *($ MOPv5T-MOPvX1)/MOPv5T

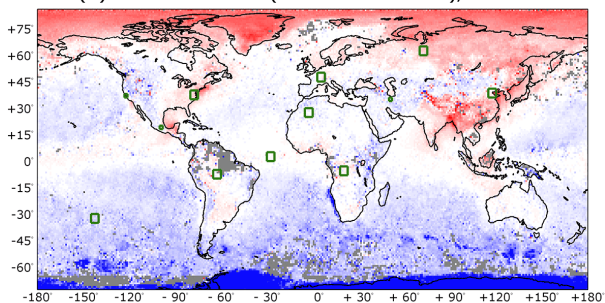

(c) 201004 100*(IASI-MOPVX1)/IASI

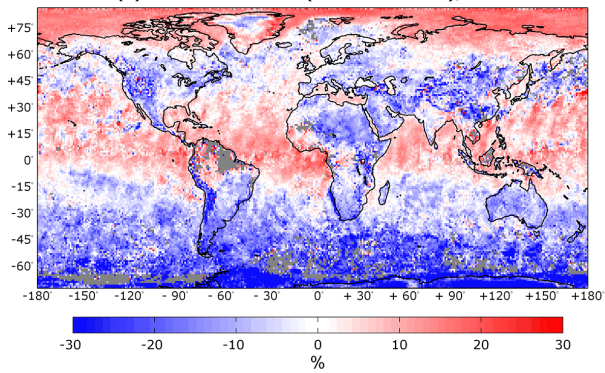

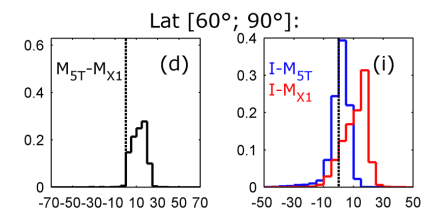

Lat $\left[20^{\circ} ; 60^{\circ}\right]$ :
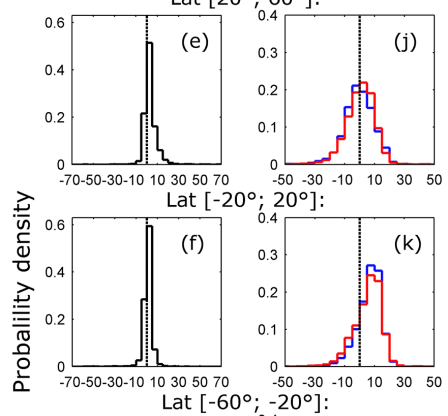

Lat $\left[-60^{\circ} ;-20^{\circ}\right]$
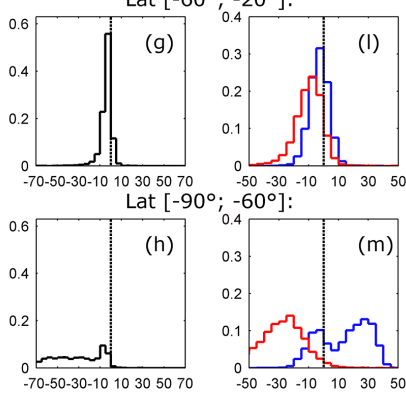

$\%$

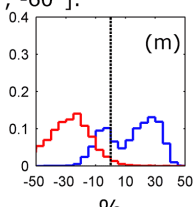

Figure 5. (a) CO total column relative differences (\%) between IASI and MOPITT v5T, (b) MOPITT v5T and MOPITT vX1 and (c) IASI and MOPITT vX1, for April 2010. The selected regions for which an in-depth study was performed are indicated with the green squares in (b) (also see Table 2 for the corresponding lon/lat information). On the right hand side (subplots $\mathbf{d}$ to $\mathbf{m}$ ), probability density functions of relative differences by $30^{\circ} / 40^{\circ}$ latitude bands, between MOPITT v5T and MOPITT vX1 (in black), between IASI and MOPITT v5T (in blue) and between IASI and MOPITT vX1 (in red).

erally range between -5 and $5 \%$, with the MOPITT v5T columns being larger than the vX1 ones above some emissions sources (USA's east coast, Mexico and China). This can be explained by the MOPITT v5T climatology-based a priori, which is closer to the real atmospheric state, including higher levels of $\mathrm{CO}$ above emissions sources.

From Fig. 5a and c we see that the reprocessing of MOPITT data slightly improves the agreement with IASI over the USA's east coast and China, i.e., for regions where emission sources are usually high. Between $20^{\circ} \mathrm{S}$ and $20^{\circ} \mathrm{N}$ and between 20 and $60^{\circ} \mathrm{N}$, the statistics are alike: when looking at the histograms (Fig. 5i-m), the probability density functions $(100 \times($ IASI-MOPITT v5T)/IASI and $100 \times($ IASIMOPITT vX1)/IASI) look similar. But in the Southern Hemisphere between 20 and $60^{\circ} \mathrm{S}$ the reprocessing of MOPITT does not reconcile the differences with IASI, in fact the difference percentages are larger for the comparison with MOPITT vX1 (the probability density functions peaks at $-10 \%$, and it was $-5 \%$ with v5T), and it is the same at high northern latitudes ( $20 \%$ for vX1 compared to $5 \%$ for v5T). Finally, the differences are about the same amplitude in Antarctica, but with the opposite sign ( $-30 \%$ for vX1 and $+30 \%$ for v5T).

These differences will be discussed in details in the next two sections.

\subsection{Impact of the change of a priori on selected regions}

In order to investigate the observed differences, a detailed analysis was performed over the 6-year seasonal record, on 12 selected regions spread over the globe (listed in Table 2, and also identified by green boxes in Fig. $5 b$ ). The areas are representative of different ecosystems (water, sand, forest) and of various seasonal $\mathrm{CO}$ atmospheric content (cities, fire seasonal activity, background). The size of the grid boxes $\left(5^{\circ} \times 5^{\circ}\right.$ for nine regions and $2^{\circ} \times 2^{\circ}$ for three cities) was chosen so that the number of data is statistically significant for each instrument. For each box, 15-day averages of $\mathrm{CO}$ total column values are calculated, provided data from both MOPITT and IASI are available for each day. Typically, each grid box contains about 500 MOPITT and 850 IASI pixels. Table 2 lists the biases and the absolute biases, along with 
Table 2. Column 1: name and localization (latitude; longitude) of the 12 selected regions. Columns 2 and 3: mean bias (\%) over the 20082013 time period and corresponding SD between IASI and MOPITT v5T CO total column. Columns 4 and 5 (in italic): the same but for IASI and MOPITT vX1. Columns 6 and 7: absolute mean bias $(100 \times(\mid$ IASI-MOPITT|)/IASI) and corresponding SD. Columns 8 and 9 (in italic): the same but for IASI and MOPITT vX1. For the "Europe", "Siberia" and "USA" regions, the bold values correspond to the December and January months (DJ). Columns $10\left(r_{5 \mathrm{~T}}\right)$ and $11\left(r_{\mathrm{X} 1}\right)$ : correlation coefficients between IASI and MOPITT v5T and MOPITT vX1, respectively.

\begin{tabular}{|c|c|c|c|c|c|c|c|c|c|c|}
\hline \multirow[b]{2}{*}{ Regions } & \multicolumn{2}{|c|}{ IASI/MOPITT v5T } & \multicolumn{2}{|c|}{ IASI/MOPITT vX1 } & \multicolumn{2}{|c|}{ IASI/MOPITT v5T } & \multicolumn{2}{|c|}{ IASI/MOPITT vX1 } & \multirow[t]{2}{*}{$r_{5 \mathrm{~T}}$} & \multirow[t]{2}{*}{$r_{\mathrm{X} 1}$} \\
\hline & Mean bias & Mean SD & Mean bias & Mean SD & $\begin{array}{l}\text { Mean abs } \\
\text { bias }\end{array}$ & Mean SD & $\begin{array}{l}\text { Mean abs } \\
\text { bias }\end{array}$ & Mean SD & & \\
\hline $\begin{array}{l}\text { Pacific } \\
{\left[\left(-35^{\circ},-30^{\circ} \mathrm{N}\right)\right.} \\
\left.\left(-145^{\circ},-140^{\circ} \mathrm{E}\right)\right]\end{array}$ & -5.3 & 8.2 & -11.5 & 8.3 & 8 & 5.7 & 12.4 & 7 & 0.86 & 0.88 \\
\hline $\begin{array}{l}\text { Atlantic } \\
{\left[\left(0,5^{\circ} \mathrm{N}\right)\right.} \\
\left.\left(-30^{\circ},-25^{\circ} \mathrm{E}\right)\right]\end{array}$ & 10.8 & 4.3 & 12.6 & 5.1 & 10.8 & 4.2 & 12.6 & 5.1 & 0.92 & 0.89 \\
\hline $\begin{array}{l}\text { Forest } \\
{\left[\left(-10^{\circ},-5^{\circ} \mathrm{N}\right) ;\right.} \\
\left.\left(-65^{\circ},-60^{\circ} \mathrm{E}\right)\right]\end{array}$ & 4.4 & 8.1 & 6.5 & 7.5 & 7.4 & 5.5 & 8 & 5.9 & 0.94 & 0.95 \\
\hline $\begin{array}{l}\text { Desert } \\
{\left[\left(25^{\circ}, 30^{\circ} \mathrm{N}\right)\right.} \\
\left.\left(-5^{\circ} \mathrm{E}, 0\right)\right]\end{array}$ & -10.7 & 4.2 & -10.9 & 4.1 & 10.7 & 4.2 & 10.9 & 4.1 & 0.95 & 0.95 \\
\hline $\begin{array}{l}\text { Africa } \\
{\left[\left(-8^{\circ},-3^{\circ} \mathrm{N}\right)\right.} \\
\left.\left(18^{\circ}, 23^{\circ} \mathrm{E}\right)\right]\end{array}$ & -0.3 & 10.3 & 3.9 & 8.5 & 8.6 & 5.6 & 7.3 & 5.9 & 0.91 & 0.94 \\
\hline $\begin{array}{l}\text { China } \\
{\left[\left(36^{\circ}, 41^{\circ} \mathrm{N}\right) ;\right.} \\
\left.\left(115^{\circ}, 120^{\circ} \mathrm{E}\right)\right]\end{array}$ & -3.8 & 16.3 & 12.9 & 13.6 & 12.8 & 10.7 & 16.1 & 9.6 & 0.63 & 0.72 \\
\hline $\begin{array}{l}\text { Europe } \\
{\left[\left(45^{\circ}, 50^{\circ} \mathrm{N}\right)\right.} \\
\left.\left(3^{\circ}, 8^{\circ} \mathrm{E}\right)\right]\end{array}$ & $\begin{array}{l}-15.7 \\
-35 \text { DJ }\end{array}$ & $\begin{array}{l}13.3 \\
\text { 8.8 DJ }\end{array}$ & $\begin{array}{l}-8.2 \\
-18.1 \mathrm{DJ}\end{array}$ & $\begin{array}{l}8.7 \\
6.7 \mathrm{DJ}\end{array}$ & $\begin{array}{l}16.2 \\
\text { 35 DJ }\end{array}$ & $\begin{array}{l}12.6 \\
\text { 8.8 DJ }\end{array}$ & $\begin{array}{l}9.3 \\
18.1 \mathrm{DJ}\end{array}$ & $\begin{array}{l}7.6 \\
6.7 \mathrm{DJ}\end{array}$ & 0.65 & 0.84 \\
\hline $\begin{array}{l}\text { Siberia } \\
{\left[\left(60^{\circ}, 65^{\circ} \mathrm{N}\right)\right.} \\
\left.\left(70^{\circ}, 75^{\circ} \mathrm{E}\right)\right]\end{array}$ & $\begin{array}{l}-16.5 \\
-35.9 \text { DJ }\end{array}$ & $\begin{array}{l}17.5 \\
9.5 \text { DJ }\end{array}$ & $\begin{array}{l}-6.1 \\
-12.6 \mathrm{DJ}\end{array}$ & $\begin{array}{l}9.1 \\
8.7 \mathrm{DJ}\end{array}$ & $\begin{array}{l}18.7 \\
35.9 \text { DJ }\end{array}$ & $\begin{array}{l}15.1 \\
9.5 \text { DJ }\end{array}$ & $\begin{array}{l}8.4 \\
12.9 \mathrm{DJ}\end{array}$ & $\begin{array}{l}7 \\
8.2 \mathrm{DJ}\end{array}$ & 0.28 & 0.77 \\
\hline $\begin{array}{l}\text { Mexico city } \\
{\left[\left(18^{\circ}, 20^{\circ} \mathrm{N}\right)\right.} \\
\left.\left(-100^{\circ},-98^{\circ} \mathrm{E}\right)\right]\end{array}$ & -8.4 & 6.1 & -11.5 & 7.9 & 8.8 & 5.5 & 11.8 & 7.4 & 0.93 & 0.9 \\
\hline $\begin{array}{l}\text { Teheran } \\
{\left[\left(34^{\circ}, 36^{\circ} \mathrm{N}\right)\right.} \\
\left.\left(50^{\circ}, 52^{\circ} \mathrm{E}\right)\right]\end{array}$ & -12.9 & 5.1 & -13.1 & 5.7 & 12.9 & 5.1 & 13.3 & 5.4 & 0.86 & 0.87 \\
\hline $\begin{array}{l}\text { San Francisco } \\
{\left[\left(36^{\circ}, 38^{\circ} \mathrm{N}\right)\right.} \\
\left.\left(-123^{\circ},-121^{\circ} \mathrm{E}\right)\right]\end{array}$ & -11.7 & 7.4 & -5.5 & 7.9 & 12.3 & 6.4 & 7.8 & 5.5 & 0.89 & 0.86 \\
\hline $\begin{array}{l}\mathrm{USA} \\
{\left[\left(35^{\circ}, 40^{\circ} \mathrm{N}\right)\right.} \\
\left.\left(-80^{\circ},-75^{\circ} \mathrm{E}\right)\right]\end{array}$ & $\begin{array}{l}-15.1 \\
-27.2 \text { DJ }\end{array}$ & $\begin{array}{l}8.5 \\
5.3 \text { DJ }\end{array}$ & $\begin{array}{l}-2.9 \\
-11.4 \mathrm{DJ}\end{array}$ & $\begin{array}{l}6.6 \\
5.3 \mathrm{DJ}\end{array}$ & $\begin{array}{l}15.1 \\
27.2 \text { DJ }\end{array}$ & $\begin{array}{l}8.5 \\
\mathbf{5 . 3} \text { DJ }\end{array}$ & $\begin{array}{l}5.4 \\
11.4 \mathrm{DJ}\end{array}$ & $\begin{array}{l}4.8 \\
5.3 \mathrm{DJ}\end{array}$ & 0.82 & 0.87 \\
\hline
\end{tabular}

their standard deviation (SD), as well as the correlation coefficients for each region.

Figure 6 illustrates the seasonal patterns as seen by both instruments, for a subset of six regions representative of different regimes: Africa (fires), China (high concentrations and large variability), Pacific (remote sea), Siberia, USA and Europe (NH regions with large discrepancies in boreal winter). The figure provides the average and the standard deviation for IASI (in red) and MOPITT v5T (in blue), twice per month. The maxima and minima are driven by the chemical and photochemical reactions described in Sect. 3.1. It can be seen that the agreement is good in general although MOPITT columns are most of the time slightly larger for all the boxes located over land, as already discussed. The correlation coefficients $\left(r_{5 T}\right.$ and $r_{X 1}$ in Table 2) are good (range between 0.72 and 0.95 ) and generally improved by the reprocessing. The variability inside the box (standard deviation in Fig. 6) is an indicator of the rapid changes in the $\mathrm{CO}$ content occurring over the area. It is very low over the remote sea (see the
Pacific box) and very high over the polluted area in China. Figure 7a provides the differences in percent for the same six areas for both the MOPITT v5T and the MOPITT vX1 processing, relatively to IASI. The grey envelopes indicate the IASI standard deviation within the box (in \%). By analyzing the time periods when the MOPITT v5T vs. IASI differences exceed this "natural" variability (i.e., when the black dots are outside the grey area in Fig. 7), we find as a consistent pattern that the MOPITT total columns sometimes exceed the IASI total columns by $\sim 30 \%$. This happens each year during the boreal winter period (December-January) for the boxes "Europe", "USA", and "Siberia" (see black rectangles and bold figures in Table 2). In the "Siberia" box, the difference can reach $50 \%$ from October to April. This is closely linked to the seasonal evolution of the information content available in the data (how much it can depart from the a priori) as can been seen from IASI DOFS plotted in Fig. 7b for the "Europe", "USA" and "Siberia" boxes. The largest biases are indeed observed in boreal winter and are associ- 


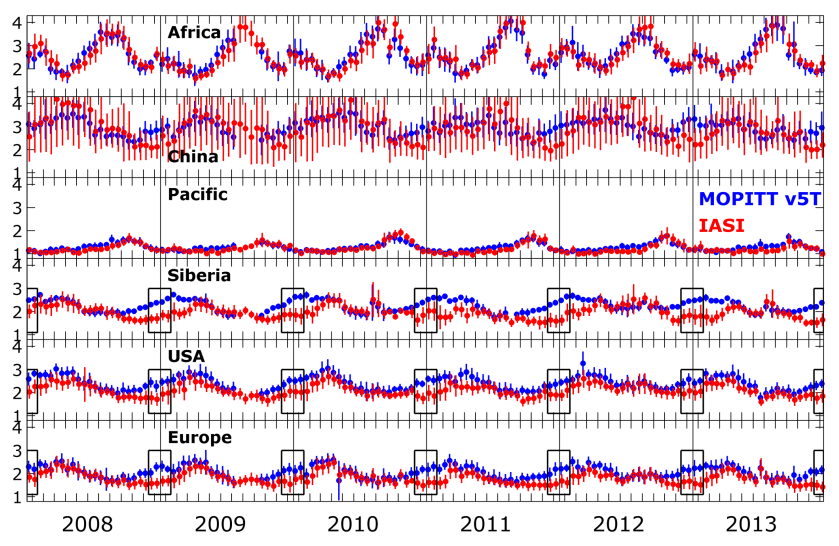

Figure 6. CO total column variability for IASI (in red) and MOPITT v5T (in blue) $\left(\times 10^{18}\right.$ molecules $\left.\mathrm{cm}^{-2}\right)$ for six selected regions (see Fig. 5b and lat/lon information in Table 2). Each point represents a 15 day-average and the vertical bar represents the SD. Black rectangles indicate the January and December months for each year, for "USA", "Europe" and "Siberia" on which we focus in Table 2.

ated with low DOFS at this time of year. Although they do not totally disappear, these biases are significantly reduced when the MOPITT data are reprocessed to derive $\mathrm{CO}$ using the IASI a priori: differences are reduced by a factor of 2 to 2.5 ("Europe": absolute mean bias of $35 \%$ in DecemberJanuary compared to $18.1 \%$ after the reprocessing; "USA": 27.2 vs. $11.4 \%$; "Siberia": 35.9 vs. $12.9 \%$ ) (see Table 2). Surprisingly, the use of the same a priori information slightly increases the biases for some other regions (Pacific, Atlantic and Mexico City), for which an in-depth analysis of averaging kernels would be needed for a complete understanding.

A global map of the differences in a priori for both missions is provided in Fig. 8, which shows the global difference between the IASI and MOPITT a priori CO data, for both January and July, at the lowest vertical level and at $400 \mathrm{hPa}$ $(\sim 7 \mathrm{~km})$. The larger differences are found near the surface, close to pollution and fire emission sources, mostly in the Northern Hemisphere, and peak in winter over the selected areas as discussed in Sect. 3.2. An in-depth look at the retrieved profiles will provide more information on how the a priori profiles and associated $\mathbf{S}_{a}$ matrix and actual observations combine.

\section{Comparison of $\mathrm{CO}$ profiles products: case studies}

\subsection{General description}

Even more than for total column values, the shape of the retrieved $\mathrm{CO}$ profiles will be determined by the vertical instrumental sensitivity, modulated by the thermal contrast which governs the sensitivity to the lower atmospheric layers, and by the a priori assumptions. If the measurement sensitivity is low and/or the background covariance is small relative to that

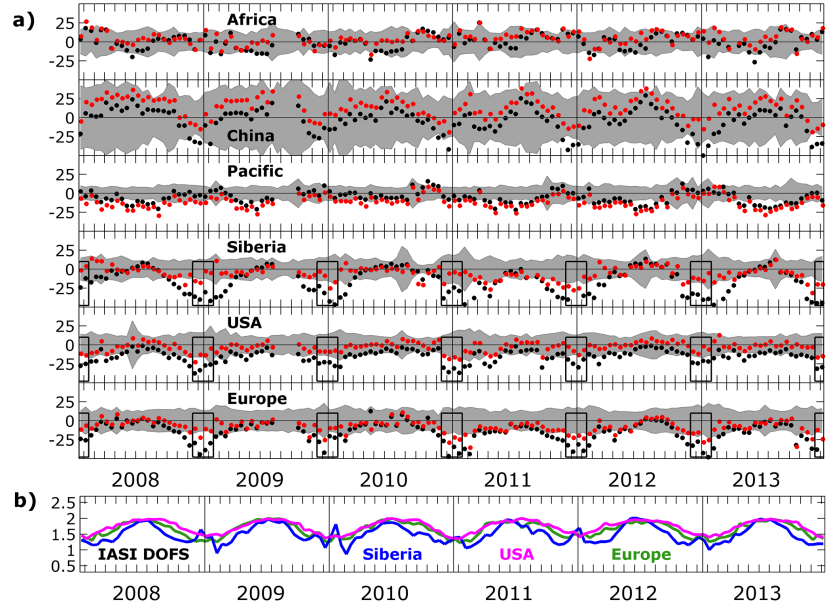

Figure 7. (a) $\mathrm{CO}$ total column relative differences (\%) between IASI and MOPITT v5T (in black) and IASI and MOPITT vX1 (in red) $(100 \times($ IASI-MOPITT)/IASI), for the six regions presented in Fig. 6. The grey area represents the IASI CO total column SD (in $\%)$. Black rectangles indicate the January and December months for each year, for "USA", "Europe" and "Siberia" on which we focus in Table 2. (b) Seasonal variability of the IASI Degree of Freedom for Signal (DOFS) corresponding to the "Siberia" (in blue), "USA" (in magenta) and "Europe" (in green) regions.
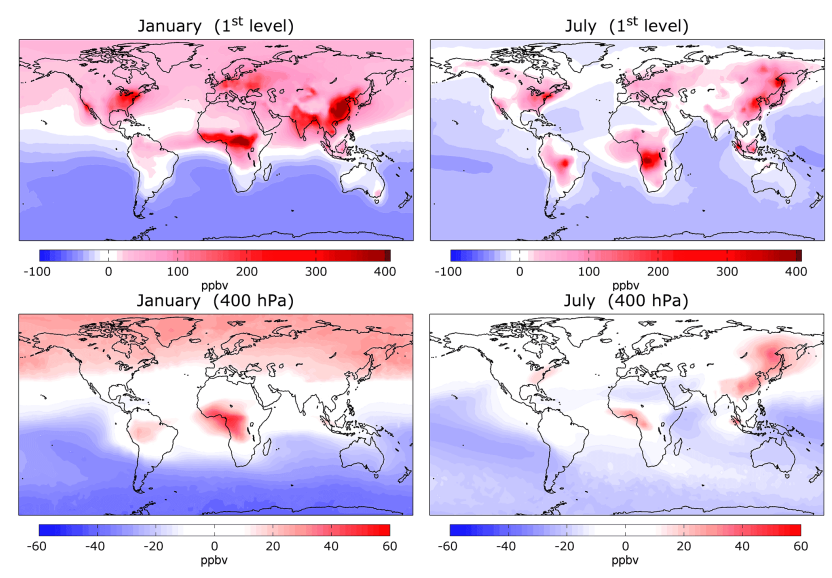

Figure 8. Difference (in ppbv) between MOPITT and IASI a priori (MOPITT-IASI), in January (left) and in July (right), near the surface (up) and at $400 \mathrm{hPa}$ (bottom).

of the measurement, then the retrieval tends toward the a priori profile value at these altitudes. When the a priori profiles differ significantly for IASI and MOPITT, large differences can appear in the retrieved profile products.

As explained in Sect. 2.2, the IASI a priori profile is always the same, and the $\mathbf{S}_{a}$ matrix allows a large variability, in particular near the surface. On the contrary MOPITT v5T a priori profiles rely on a monthly/latitudinal varying climatology, and the $\mathbf{S}_{a}$ matrix has a moderate and constant vertical variability. Thousands of $\mathrm{CO}$ data were analyzed to com- 

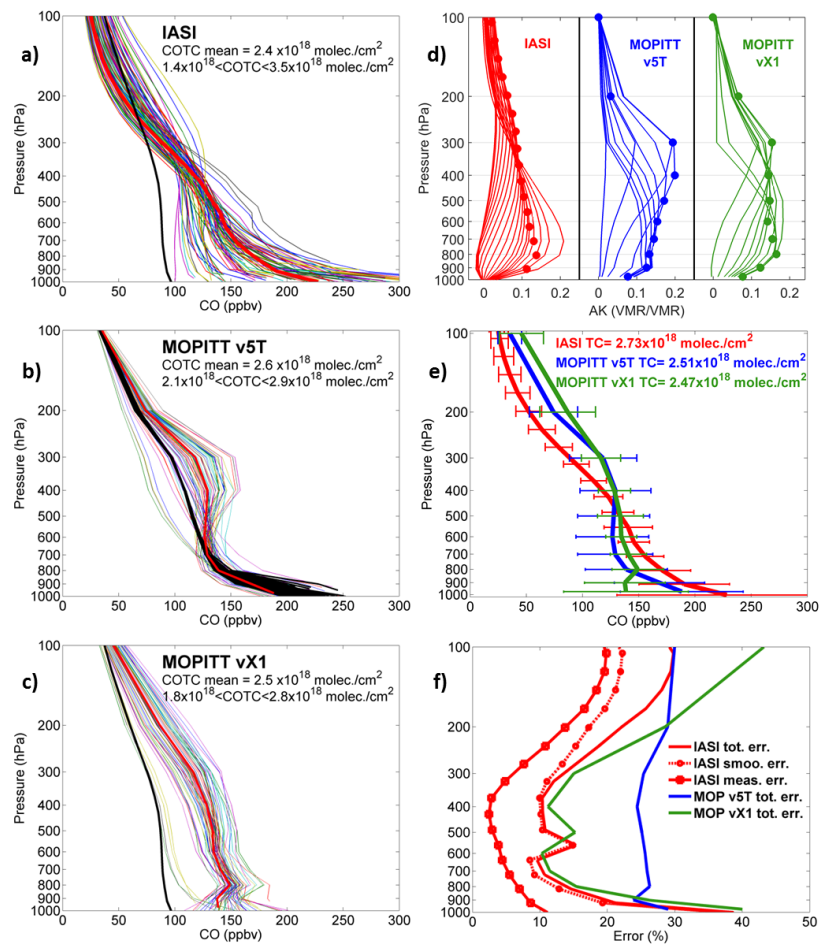

Figure 9. (a-c) Ensemble of retrieved profiles in the "Europe" box for 1 day (20100409), for IASI, MOPITT v5T, and MOPITT vX1. The corresponding a priori profiles are plotted in black. For each subplot the $\mathrm{CO}$ total columns are also provided. (d) provides the averaging kernels (the altitude of each line is indicated by a dot) for one example case (see red profiles plotted in $\mathbf{a}-\mathbf{c}$ ), (e) retrieved profiles with corresponding total error (horizontal bars) and (f) error profiles in \%. The smoothing, measurement and total errors are plotted in red for IASI. For MOPITT, only the total errors are available.

pare the profiles from both the original IASI and MOPITT v5T products, and the profiles obtained after the reprocessing (MOPITT vX1). Figure 9 illustrates a typical finding. It shows the CO profiles for 1 day of observation (9 April 2010) for the "Europe" box, when high levels of CO were observed. The total column means are similar for each product but the shape of the profiles differs. We see that the IASI-retrieved profiles (Fig. 9a), depart from the a priori at all altitudes but especially near the surface given the high variance of its $\mathbf{S}_{a}$ matrix at this altitude. For MOPITT v5T (Fig. 9b), it can be seen that the retrieved profiles remain quite close to the a priori profiles near the surface and depart at around $400 \mathrm{hPa}$, where its maximum sensitivity lies. This corresponds also to the altitude where the pressure modulated cell (PMC) channels provide most information. The quasi-diagonal MOPITT $\mathbf{S}_{a}$ matrix limits the "extrapolation" effects to the adjacent levels. Interestingly, for MOPITT vX1 (Fig. 9c), the shape of the profiles differs from the MOPITT v5T profiles and departs more from the a priori. However MOPITT $v$ X1 profiles do not show the large concentrations at the surface that IASI profiles do, despite the fact that the same a priori is used. As illustrated in Fig. 9d the averaging kernels for a representative case (in red in Fig. 9a-c) show a non-zero sensitivity at the surface for MOPITT. Another possible explanation lies in the constraint applied to the measurements (the $\mathbf{S}_{e}$ in the $\mathrm{OE}$ ), which might be looser in FORLI, increasing further the range of variability. Looking at the total errors associated with each retrieved profiles (Fig. 9e), we note that the three profiles are within the errors of each other, which indicates the consistency of the data sets. The errors in \% are plotted in Fig. 9f. The MOPITT vX1 total error profile is close to the IASI one because the smoothing error dominates.

In order to go further in the analysis we selected three illustrative cases, representative of different situations, for which aircraft profile data from the MOZAIC-IAGOS program (Nedelec et al., 2003; http://www.iagos.org/) were available within a $\pm 12 \mathrm{~h}$ time slot. Figures 10 to 12 show for different locations the IASI, MOPITT v5T and MOPITT vX1 averaged profiles with their corresponding a priori profiles, along with the collocated MOZAIC-IAGOS profile. All data within $0.5^{\circ}$ of the MOZAIC-IAGOS profile path (which corresponds to 36 to $56 \mathrm{~km}$, depending on latitude) were selected and then averaged. Note that the MOZAIC-IAGOS profiles were not smoothed by the IASI/MOPITT averaging kernels here, as we wanted to represent the actual altitude of the pollution plume if any. Representative averaging kernel functions at different altitudes are also provided for each product, in order to evaluate the altitudes where the retrievals are mostly sensitive.

\subsection{Nagoya case (high $\mathrm{CO}$ in the mid-low troposphere)}

For the "Nagoya" case plotted in Fig. 10, the MOZAICIAGOS profile shows a pollution plume around $600 \mathrm{hPa}$ $(\sim 4 \mathrm{~km})$ measured on 25 June 2012 . The shape of the collocated satellite retrieved profiles differs, with MOPITT peaking around $300-400 \mathrm{hPa}$ and at the surface, and IASI peaking at lower troposphere and at the surface. The MOPITT averaging kernel functions show that the retrieval is most sensitive just above the plume altitude, where the MOPITT v5T profile peaks. Due to the fact that there is no sensitivity at the surface the retrieved $\mathrm{CO}$ sticks to its a priori at this altitude. The IASI averaging kernel functions show a sensitivity of the retrieval slightly lower in altitude, with a maximum around $700 \mathrm{hPa}$, as well as a slight sensitivity near the surface. The IASI retrieved profile underestimates the amount of $\mathrm{CO}$ around $600 \mathrm{hPa}$ and overestimates it at surface level. Due to the loosely constrained covariance matrix near the surface, the CO amount "seen" by IASI is extrapolated toward the surface. The MOPITT vX1 profile lies "in between", with lower concentrations than the v5T one in the first layers close to the surface, and larger concentrations than the IASI profile above $400 \mathrm{hPa}$. 

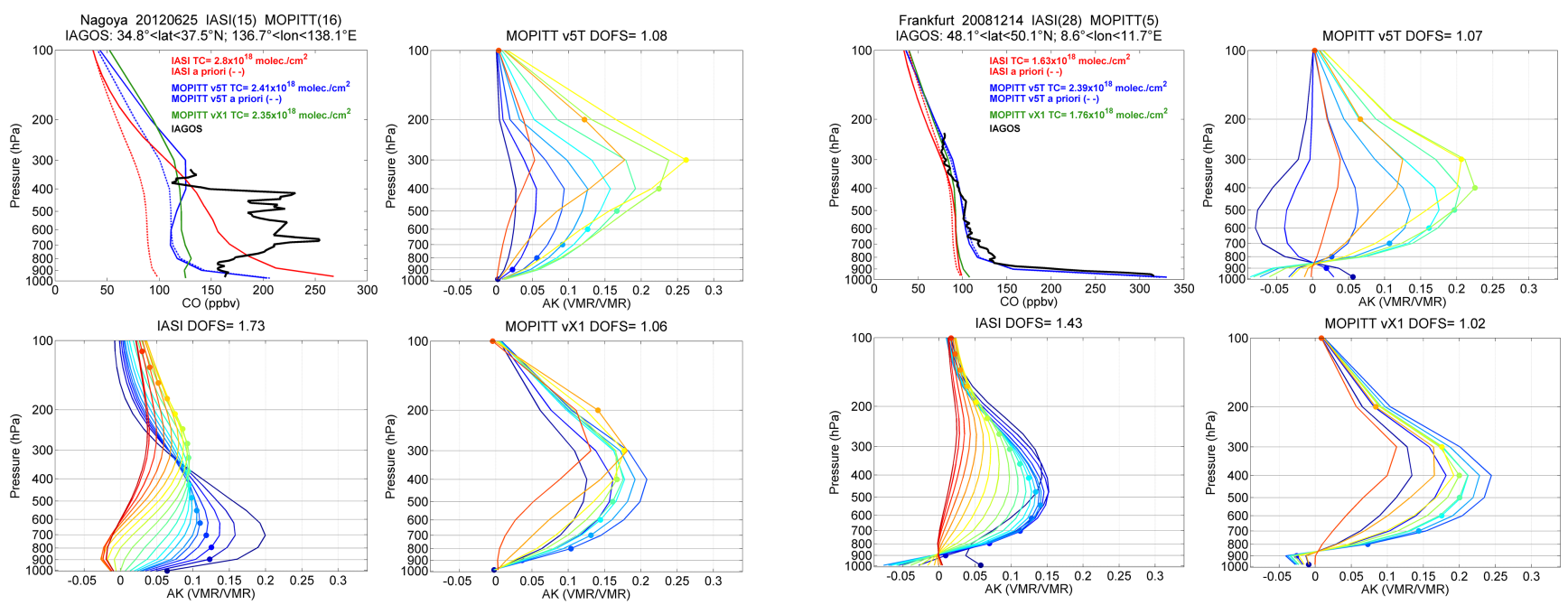

Figure 10. CO averaged profiles (upper left, red for IASI, blue for MOPITT v5T and green for MOPITT vX1) compared with collocated MOZAIC-IAGOS aircraft data (black), measured near Nagoya (Japan) on 25 June 2012. The a priori profiles are also provided (dashed line) along with the averaging kernels at different altitudes (other subplots). The following criteria were used to generate the averaged profiles: all data within $0.5^{\circ}$ of the MOZAIC-IAGOS profile path and within a $\pm 12 \mathrm{~h}$ time window were selected. The title of the upper left subplot provides information on the lat/lon limits of the MOZAIC-IAGOS profile path and the number of averaged profiles for the three products.
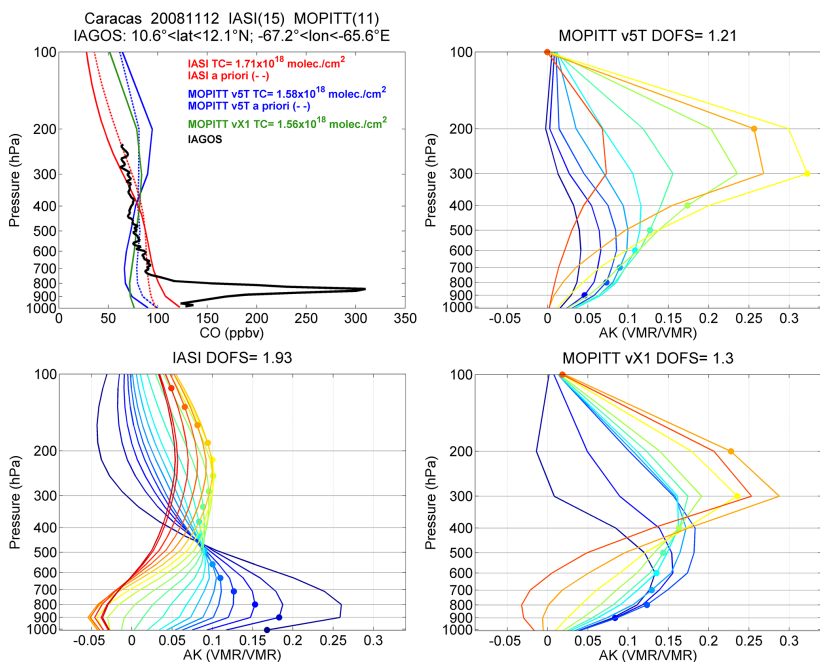

Figure 11. Same as in Fig. 10 but near Caracas (Venezuela) on 12 November 2008.

\subsection{Caracas case (high surface $\mathrm{CO}$ with sensitivity at the surface)}

The case at the Caracas airport (Fig. 11) shows a typical aircraft profile measured at this location, with $\mathrm{CO}$ mixing ratios reaching more than $300 \mathrm{ppbv}$ around $900-800 \mathrm{hPa}(1-2 \mathrm{~km})$.

Figure 12. Same as in Fig. 10 but near Frankfurt (Germany) on 14 December 2008.

The total columns retrieved by both MOPITT v5T and IASI are quite similar, but again the shape of the profiles differs. The IASI retrieval shows some sensitivity close to the surface as the averaging kernel functions associated with the lower altitudes peak between 700 and $900 \mathrm{hPa}$. The IASI profile somewhat departs from the a priori for the first altitude levels but it does not reach the MOZAIC-IAGOS high values. On the other hand, the altitude of MOPITT retrieval sensitivity maximum is higher, around $300 \mathrm{hPa}(\sim 9 \mathrm{~km})$ and its sensitivity is low near the surface. MOPITT does not capture the plume ( $-40 \mathrm{ppbv}$ compared to IASI near the surface), and the retrieved profiles (v5T and vX1) are close to their a priori profiles (and the climatology is far from the observation in this case).

\subsection{Frankfurt case (high $\mathrm{CO}$ at the surface)}

The "Frankfurt" case (Fig. 12) shows large mixing ratios measured by the MOZAIC-IAGOS aircraft near the surface. Both MOPITT and IASI are sensitive in the mid troposphere (between 500 and $300 \mathrm{hPa}$ ) but not at the surface. All the retrieved profiles stick to their a priori profiles, especially at the surface. The MOPITT v5T profile agrees very well with the MOZAIC-IAGOS profile, sticking to the a priori profile which in this case shows large mixing ratios at the surface (reaching more than $250 \mathrm{ppb}$ ). For IASI, the plume is missed and for MOPITT vX1, the profile behaves similarly to the IASI profile.

These three cases were selected to illustrate the impacts of choosing a single or a variant a priori profile and a strongly or loosely constrained $\mathbf{S}_{a}$ matrix. In summary, when there is a good sensitivity of the satellite instrument at the altitude of the plume, both instruments manage to detect the $\mathrm{CO}$ increase, but MOPITT generally puts it where its maximum sensitivity lies (around $300-400 \mathrm{hPa}$ ), whereas IASI tends to 
project high $\mathrm{CO}$ observed in the middle-troposphere towards the surface (because of the $5 \mathrm{~km}$ correlation length). For the altitudes where the instrument is not sensitive, in particular at the surface level when the thermal contrast is low, each instrument sticks to its a priori. This leads to a better agreement for the MOPITT-retrieved profile when the measured $\mathrm{CO}$ profile at one location is close to the climatology used to build the a priori, which is usually the case for seasonal fires and highly polluted areas (e.g., Frankfurt). On the contrary, for situations where unexpected fires or pollution events occur (e.g., near Caracas) the agreement is better with the IASI derived profile.

In order to confirm the important role of the choice of the a priori assumptions and especially the weight of the $\mathbf{S}_{a}$ matrix, we also performed some tests processing the IASI algorithm with the MOPITT $\mathbf{S}_{a}$ matrix (but with the single IASI a priori profile). As expected, the reprocessed IASI profiles (not shown here) show lower CO concentration than the native IASI profiles near the surface because the allowed variability (used for MOPITT) around the a priori profile is lower.

\section{Discussion and conclusion}

$\mathrm{CO}$ is a key atmospheric species to be analyzed on the global scale, as a precursor of other gases, and as a sink for $\mathrm{OH}$, which contributes largely to the removal of many pollutants. Since the year 2000 there have been several satellite borne instruments able to map $\mathrm{CO}$ on the global scale, including MOPITT and IASI, two different instruments that have been providing long-term radiance observations from space, from which $\mathrm{CO}$ concentrations can be derived. Because of the illposed character of the inverse problem, the choice of the a priori impacts strongly on the retrieved profiles and columns. We have investigated this by reprocessing a 6-year MOPITT data set using the same a priori constraints as those used for IASI.

For total columns we found that it leads to a better agreement for source regions and during periods of low sensitivity (such as boreal winter months at mid-latitude) where the differences in total columns are largely reduced. A priori assumptions are thought to be the dominant component of the observed discrepancies, but bias differences remain (ranging from 5 to $18 \%$ ) and can be explained by a combination of (1) the different time and location for the observations, (2) the different vertical sensitivity of each instrument, and (3) the different auxiliary parameters (in particular temperature, water vapor and cloud content) used in the retrieval.

For vertical profiles, the comparison was achieved above selected sites where correlative aircraft measurements were available. We show that when the sensitivity is good, both instruments detect $\mathrm{CO}$ concentrations increases but as expected the shape of the profiles differs. When the sensitivity is low, MOPITT-retrieved CO profiles are closer to the aircraft ones than IASI when the a priori profile is already close to the truth. When the opposite occurs (large variation from the a priori profile) IASI provides a more realistic CO profile. It proved to be difficult to find collocated observations for profile data, which limits our ability to generalize these findings. Note that data with a single a priori are also easier to interpret.

MOPITT and IASI are currently both being assimilated into the Monitoring Atmospheric Composition and Climate (MACC) system (the pre-operational Copernicus Atmosphere Service of the European Union, see http://www. copernicus.eu/), which provides analyses and forecasts of global reactive gases and aerosol fields (Inness et al., 2013). The assimilation system relies on $\mathrm{CO}$ total column and averaging kernel information, provided by retrieval algorithms described in this paper. Known discrepancies exist between the model and the $\mathrm{CO}$ satellite observed data, which have been reported in previous publications (e.g., Stein et al., 2014), but also among the satellite data themselves as demonstrated here. This is accounted for in the assimilation process by using a bias correction scheme for the $\mathrm{CO}$ data. Validation with ground-based observations (Wagner et al., 2015) pointed to the need for a more detailed assessment of both data sets, and clearer identification of where differences come from. This work is a step in that direction.

On a longer term/climate perspective, essential climate variables (ECVs) are needed for all climate related gases. This requires continuous and unbiased long-term data records. MOPITT initiated a record of more than 15 years, which is being continued for the next $>30$ years by the IASI series of instruments, with the launch of MetOp-C currently scheduled at the end of 2018, and the IASI-New Generation instruments to be embarked on the MetOp-SG platforms (Clerbaux and Crevoisier, 2013; Crevoisier et al., 2014). A systematic processing of both data sets using the same a priori assumptions is foreseen in the framework of the EU-FP7 projects QA4ECV, and this work is paving the way for establishing such a long-term CO compatible record. Our analysis is limited to the study of the impact of the a priori assumptions (probably the dominant factor for discrepancy), whereas other variables are known to contribute to the observed differences, in particular cloud content and temperature profiles. For long-term records and trend analysis it should be envisaged to reprocess the whole MOPITT-IASI series using auxiliary data coming from the same source, e.g., ECMWF (European Centre for Medium-Range Weather Forecasts) Reanalysis (ERA) for winds, cloud cover and relative humidity (Dee et al., 2011). Regarding the differences in time and location, as well as in vertical sensitivity, only data assimilation can process each data set accordingly. 
Acknowledgements. The French scientists are very grateful to NCAR and its visitor program, which allowed the fruitful scientific collaboration between the IASI and MOPITT teams to develop and to be maintained for years. NCAR is sponsored by the National Science Foundation. IASI is a joint mission of EUMETSAT and the Centre National d'Etudes Spatiales (CNES, France). The IASI L1 and L2 input data are distributed in near real time by EUMETSAT through the EumetCast system distribution. The MOPITT project is supported by the NASA Earth Observing System (EOS) Program. The MOPITT team also acknowledges support under NASA grant NNX11AE19G. The authors acknowledge the European Commission for the support to the MOZAIC project (1994-2003) and the preparatory phase of IAGOS (2005-2012). The LATMOS team also acknowledges the French Ether atmospheric database (www.pole-ether.fr) for providing the IASI L1C data and L2 temperature data disseminated via EUMETcast, as well as CNES and CNRS for financial support. This work is also part of the EUMETSAT/O3M-SAF project. The research in Belgium is funded by the Belgian State Federal Office for Scientific, Technical and Cultural Affairs and the European Space Agency (ESA Prodex arrangement 4000111403 IASI.Flow) and by the EU-FP7 projects QA4ECV (grant agreement 607405) and PANDA (grant agreement 606719). P.-F. Coheur is Senior Research Associate with F.R.S-FNRS.

Edited by: J.-L. Attie

\section{References}

Aumann, H. H., Chahine, M. T., Gautier, C., Goldberg, M. D., Kalnay, E., McMillin, L. M., Revercomb, H., Rosenkranz, P. W., Smith, W. L., Staelin, D. H., Strow, L. L., and Susskind, J.: AIRS/AMSU/HSB on the Aqua mission: design, science objectives, data products, and processing systems, IEEE T. Geosci. Remote, 41, 2, 253-264, 2003.

Beer, R.: TES on the AURA mission: scientific objectives, measurements and analysis overview, IEEE T. Geosci. Remote, 44, 1102-1105, 2006.

Clerbaux, C. and Crevoisier, C.: New Directions: infrared remote sensing of the troposphere from satellite: less, but better, Atmos. Environ., 72, 24-26, doi:10.1016/j.atmosenv.2013.01.057, 2013.

Clerbaux, C., Hadji-Lazaro, J., Payan, S., Camy-Peyret, C., Wang, J., Edwards, D. P., and Luo, M.: Retrieval of CO from nadir remote-sensing measurements in the infrared by use of four different inversion algorithms, Appl. Optics, 41, 7068-7078, doi:10.1364/AO.41.007068, 2002.

Clerbaux, C., Edwards, D. P., Deeter, M., Emmons, L., Lamarque, J.-F., Tie, X. X., Massie, S. T., and Gille, J.: Carbon monoxide pollution from cities and urban areas observed by the Terra/MOPITT mission, Geophys. Res. Lett, 35, L03817, doi:10.1029/2007GL032300, 2008.

Clerbaux, C., Boynard, A., Clarisse, L., George, M., HadjiLazaro, J., Herbin, H., Hurtmans, D., Pommier, M., Razavi, A., Turquety, S., Wespes, C., and Coheur, P.-F.: Monitoring of atmospheric composition using the thermal infrared IASI/MetOp sounder, Atmos. Chem. Phys., 9, 6041-6054, doi:10.5194/acp9-6041-2009, 2009.
Crevoisier, C., Clerbaux, C., Guidard, V., Phulpin, T., Armante, R., Barret, B., Camy-Peyret, C., Chaboureau, J.-P., Coheur, P.-F., Crépeau, L., Dufour, G., Labonnote, L., Lavanant, L., HadjiLazaro, J., Herbin, H., Jacquinet-Husson, N., Payan, S., Péquignot, E., Pierangelo, C., Sellitto, P., and Stubenrauch, C.: Towards IASI-New Generation (IASI-NG): impact of improved spectral resolution and radiometric noise on the retrieval of thermodynamic, chemistry and climate variables, Atmos. Meas. Tech., 7, 4367-4385, doi:10.5194/amt-7-4367-2014, 2014.

Dee, D. P., Uppala, S. M., Simmons, A. J., Berrisford, P., Poli, P., Kobayashi, S., Andrae, U., Balmaseda, M. A., Balsamo, G., Bauer, P., Bechtold, P., Beljaars, A. C. M., van de Berg, L., Bidlot, J., Bormann, N., Delsol, C., Dragani, R., Fuentes, M., Geer, A. J., Haimberger, L., Healy, S. B., Hersbach, H., Hólm, E. V., Isaksen, L, Kållberg, P., Köhler, M., Matricardi, M., McNally, A. P., Monge-Sanz, B. M., Morcrette, J.-J., Park, B.-K., Peubey, C., de Rosnay, P., Tavolato, C., Thépaut J.-N., and Vitart, F.: The ERA-Interim reanalysis: configuration and performance of the data assimilation system, Q. J. Roy. Meteor. Soc., 137, 553-597, 2011.

Deeter, M. N., Emmons, L. K., Francis, G. L., Edwards, D. P., Gille, J. C., Warner, J. X., Khattatov, B., Ziskin, D., Lamarque, J. F., Ho, S. P., Yudin, V., Attié, J. L., Packman, D., Chen, J., Mao, D., and Drummond, J. R.: Operational carbon monoxide retrieval algorithm and selected results for the MOPITT instrument, J. Geophys. Res., 108, 4399, doi:10.1029/2002JD003186, 2003.

Deeter, M. N., Edwards, D. P., Gille, J. C., and Drummond, J. R.: Sensitivity of MOPITT observations to carbon monoxide in the lower troposphere, J. Geophys. Res., 112, D24306, doi:10.1029/2007JD008929, 2007.

Deeter, M. N., Edwards, D. P., Gille, J. C, Emmons, L. K., Francis, G., Ho, S.-P., Mao, D., Masters, D., Worden, H., Drummond, J. R., and Novelli, P. C.: The MOPITT version 4 CO product: algorithm enhancements, validation, and long-term stability, J. Geophys. Res., 115, D07306, doi:10.1029/2009JD013005, 2010.

Deeter, M. N., Worden, H. M., Edwards, D. P., Gille, J. C., and Andrews, A. E.: Evaluation of MOPITT retrievals of lowertropospheric carbon monoxide over the United States, J. Geophys. Res., 117, D13306, doi:10.1029/2012JD017553, 2012.

Deeter, M. N., Martínez-Alonso, S., Edwards, D. P., Emmons, L. K., Gille, J. C., Worden, H. M., Pittman, J. V., Daube, B. C., and Wofsy, S. C.: Validation of MOPITT Version 5 thermalinfrared, near-infrared, and multispectral carbon monoxide profile retrievals for 2000-2011, J. Geophys. Res., 118, 6710-6725, doi:10.1002/jgrd.50272, 2013.

De Wachter, E., Barret, B., Le Flochmoën, E., Pavelin, E., Matricardi, M., Clerbaux, C., Hadji-Lazaro, J., George, M., Hurtmans, D., Coheur, P.-F., Nedelec, P., and Cammas, J. P.: Retrieval of MetOp-A/IASI CO profiles and validation with MOZAIC data, Atmos. Meas. Tech., 5, 2843-2857, doi:10.5194/amt-52843-2012, 2012.

Drummond, J. R. and Mand, G. S.: The Measurements of Pollution in the Troposphere (MOPITT) Instrument: Overall Performance and Calibration Requirements, J. Atmos. Ocean. Tech., 13, 314-320, doi:10.1175/15200426(1996)013<0314:TMOPIT>2.0.CO;2, 1996. 
Drummond, J. R., Zou, J., Nichitiu, F., Kar, J., Deschambaut, R., and Hackett, J.: A review of 9-year performance and operation of the MOPITT instrument, Adv. Space Res., 45, 760-774, doi:10.1016/j.asr.2009.11.019, 2010.

Duncan, B. N. and Logan, J. A.: Model analysis of the factors regulating the trends and variability of carbon monoxide between 1988 and 1997, Atmos. Chem. Phys., 8, 7389-7403, doi:10.5194/acp-8-7389-2008, 2008.

Edwards, D. P., Halvorson, C. M., and Gille, J. C.: Radiative transfer modeling for the EOS Terra satellite Measurement of Pollution in the Troposphere (MOPITT) instrument, J. Geophys. Res., 104, 16755-16775, doi:10.1029/1999JD900167, 1999.

Edwards, D. P., Emmons, L. K., Gille, J. C., Chu, A., Attié, J.L., Giglio, L., Wood, S. W., Haywood, J., Deeter, M. N., Massie, S. T., Ziskin, D. C., and Drummond, J. R.: Satellite observed pollution from Southern Hemisphere biomass burning, J. Geophys. Res., 111, D14312, doi:10.1029/2005JD006655, 2006.

Emmons, L. K., Deeter, M. N., Gille, J. C., Edwards, D. P., Attié, J.-L., Warner, J., Ziskin, D., Francis, G., Khattatov, B., Yudin, V., Lamarque, J.-F., Ho, S.-P., Mao, D., Chen, J. S., Drummond, J., Novelli, P., Sachse, G., Coffey, M. T., Hannigan, J. W., Gerbig, C., Kawakami, S., Kondo, Y., Takegawa, N., Schlager, H., Baehr, J., and Ziereis, H.: Validation of Measurements of Pollution in the Troposphere (MOPITT) CO retrievals with aircraft in situ profiles, J. Geophys. Res., 109, D03309, doi:10.1029/2003JD004101, 2004.

Emmons, L. K., Edwards, D. P., Deeter, M. N., Gille, J. C., Campos, T., Nédélec, P., Novelli, P., and Sachse, G.: Measurements of Pollution In The Troposphere (MOPITT) validation through 2006, Atmos. Chem. Phys., 9, 1795-1803, doi:10.5194/acp-91795-2009, 2009.

Gambacorta, A., Barnet, C., Wolf, W., King, T., Maddy, E., Strow, L., Xiong. X., Nalli, N., and Goldberg, M.: An experiment using high spectral resolution CrIS measurements for atmospheric trace gases: carbon monoxide retrieval impact study, IEEE Geosci. Remote Sens. Lett., 11, 9, 1639-1643, doi:10.1109/LGRS.2014.2303641, 2014.

George, M., Clerbaux, C., Hurtmans, D., Turquety, S., Coheur, P.F., Pommier, M., Hadji-Lazaro, J., Edwards, D. P., Worden, H., Luo, M., Rinsland, C., and McMillan, W.: Carbon monoxide distributions from the IASI/METOP mission: evaluation with other space-borne remote sensors, Atmos. Chem. Phys., 9, 8317-8330, doi:10.5194/acp-9-8317-2009, 2009.

Ho, S., Edwards, D. P., Gille, J. C., Luo, M., Osterman, G. B., Kulawik, S. S., and Worden, H.: A global comparison of carbon monoxide profiles and column amounts from Tropospheric Emission Spectrometer (TES) and Measurements of Pollution in the Troposphere (MOPITT), J. Geophys. Res., 114, D21307, doi:10.1029/2009JD012242, 2009.

Hemispheric Transport of Air Pollution (HTAP): Part 1: Ozone and Particulate matter, United Nations Publications, available at: http://www.htap.org/publications/assessment_reports. htm (last access: 29 September 2015), 2010.

Hurtmans, D., Coheur, P.-F., Wespes, C., Clarisse, L., Scharf, O., Clerbaux, C., Hadji-Lazaro, J., George, M., and Turquety, S.: FORLI radiative transfer and retrieval code for IASI, J. Quant. Spectrosc. Ra., 113, 1391-1408, doi:10.1016/j.jqsrt.2012.02.036, 2012.
IASI Science Plan, C. Camy-Peyret, J. Eyre et al., ISSWG/Eumetsat, available at: https://iasi.cnes.fr/sites/default/ files/migration/smsc/iasi/IASI_Science_Plan_Issue1_released_ version.pdf (last access: 29 September 2015), 1998.

Illingworth, S. M., Remedios, J. J., Boesch, H., Ho, S.-P., Edwards, D. P., Palmer, P. I., and Gonzi, S.: A comparison of OEM CO retrievals from the IASI and MOPITT instruments, Atmos. Meas. Tech., 4, 775-793, doi:10.5194/amt-4-775-2011, 2011.

Inness, A., Baier, F., Benedetti, A., Bouarar, I., Chabrillat, S., Clark, H., Clerbaux, C., Coheur, P., Engelen, R. J., Errera, Q., Flemming, J., George, M., Granier, C., Hadji-Lazaro, J., Huijnen, V., Hurtmans, D., Jones, L., Kaiser, J. W., Kapsomenakis, J., Lefever, K., Leitão, J., Razinger, M., Richter, A., Schultz, M. G., Simmons, A. J., Suttie, M., Stein, O., Thépaut, J.-N., Thouret, V., Vrekoussis, M., Zerefos, C., and the MACC team: The MACC reanalysis: an 8 yr data set of atmospheric composition, Atmos. Chem. Phys., 13, 4073-4109, doi:10.5194/acp-13-4073-2013, 2013.

Kerzenmacher, T., Dils, B., Kumps, N., Blumenstock, T., Clerbaux, C., Coheur, P.-F., Demoulin, P., García, O., George, M., Griffith, D. W. T., Hase, F., Hadji-Lazaro, J., Hurtmans, D., Jones, N., Mahieu, E., Notholt, J., Paton-Walsh, C., Raffalski, U., Ridder, T., Schneider, M., Servais, C., and De Mazière, M.: Validation of IASI FORLI carbon monoxide retrievals using FTIR data from NDACC, Atmos. Meas. Tech., 5, 2751-2761, doi:10.5194/amt-5-2751-2012, 2012.

Krol, M., Peters, W., Hooghiemstra, P., George, M., Clerbaux, C., Hurtmans, D., McInerney, D., Sedano, F., Bergamaschi, P., El Hajj, M., Kaiser, J. W., Fisher, D., Yershov, V., and Muller, J.-P.: How much CO was emitted by the 2010 fires around Moscow?, Atmos. Chem. Phys., 13, 4737-4747, doi:10.5194/acp-13-4737-2013, 2013.

Luo, M., Rinsland, C. P., Rodgers, C. D., Logan, J. A., Worden, H., Kulawik, S., Eldering, A., Goldman, A., Shephard, M. W., Gunson, M., and Lampel, M.: Comparison of carbon monoxide measurements by TES and MOPITT: influence of a priori data and instrument characteristics on nadir atmospheric species retrievals, J. Geophys. Res., 112, D09303, doi:10.1029/2006JD007663, 2007.

McMillan, W. W., Barnet, C., Strow, L., Chahine, M. T., McCourt, M. L., Warner, J. X., Novelli, P. C., Korontzi, S., Maddy, E. S., and Datta, S.: Daily global maps of carbon monoxide from NASA's Atmospheric Infrared Sounder, Geophys. Res. Lett., 32, L11801, doi:10.1029/2004GL021821, 2005.

Nedelec, P., Cammas, J.-P., Thouret, V., Athier, G., Cousin, J.-M., Legrand, C., Abonnel, C., Lecoeur, F., Cayez, G., and Marizy, C.: An improved infrared carbon monoxide analyser for routine measurements aboard commercial Airbus aircraft: technical validation and first scientific results of the MOZAIC III programme, Atmos. Chem. Phys., 3, 1551-1564, doi:10.5194/acp-3-15512003, 2003.

Pan, L. W., Edwards, D. P., Gille, J. C., Smith, M. W., and Drummond, J. R.: Satellite remote-sensing of tropospheric CO and $\mathrm{CH} 4$ - forward model studies of the MOPITT instrument, Appl. Optics, 34, 6976-6988, doi:10.1364/AO.34.006976, 1995.

Pommier, M., Law, K. S., Clerbaux, C., Turquety, S., Hurtmans, D., Hadji-Lazaro, J., Coheur, P.-F., Schlager, H., Ancellet, G., Paris, J.-D., Nédélec, P., Diskin, G. S., Podolske, J. R., Holloway, J. S., and Bernath, P.: IASI carbon monoxide 
validation over the Arctic during POLARCAT spring and summer campaigns, Atmos. Chem. Phys., 10, 10655-10678, doi:10.5194/acp-10-10655-2010, 2010.

Ponomarev, E. I.: Radiative power of wildfires in Siberia on the basis of TERRA/Modis imagery 897 processing, Folia Forestalia Polonica, Seria A, 55, 102-110, doi:10.2478/ffp-2013-00011, 2013.

R'Honi, Y., Clarisse, L., Clerbaux, C., Hurtmans, D., Duflot, V., Turquety, S., Ngadi, Y., and Coheur, P.-F.: Exceptional emissions of $\mathrm{NH}_{3}$ and $\mathrm{HCOOH}$ in the 2010 Russian wildfires, Atmos. Chem. Phys., 13, 4171-4181, doi:10.5194/acp-13-41712013, 2013.

Rinsland, C. P., Luo, M., Logan, J. A., Beer, R., Worden, H., Kulawik, S. S., Rider, D., Osterman, G., Gunson, M., Eldering, A., Goldman, A., Shephard, M., Clough, S. A., Rodgers, C., Lampel, M., and Chiou, L.: Nadir measurements of carbon monoxide (CO) distributions by the tropospheric emission spectrometer instrument onboard the Aura spacecraft: overview of analysis approach and examples of initial results, Geophys. Res. Lett., 33, L22806, doi:10.1029/2006GL027000, 2006.

Rodgers, C. D.: Inverse Methods for Atmospheric Sounding: Theory and Practice, Ser. Atmos. Ocean. Planet. Phys. 2, World Sci., Hackensack, NJ, 2000.

Stein, O., Schultz, M. G., Bouarar, I., Clark, H., Huijnen, V., Gaudel, A., George, M., and Clerbaux, C.: On the wintertime low bias of Northern Hemisphere carbon monoxide found in global model simulations, Atmos. Chem. Phys., 14, 9295-9316, doi:10.5194/acp-14-9295-2014, 2014.

Streets, D., Canty, T., Carmichael, G., de Foy, B., Dickerson, R., Duncan, B., Edwards, D., Haynes, J., Henze, D., Houyoux, M., Jacob, D., Krotkov, N., Lamsal, L., Liu, Y., Lu, Z., Martin, R., Pfister, G., Pinder, R., Salawitch, R., and Wecht, K.: Emissions estimation from satellite retrievals: a review of current capability, Atmos. Environ., 77, 1011-1042, doi:10.1016/j.atmosenv.2013.05.051, 2013.

Strode, S. A. and Pawson, S.: Detection of carbon monoxide trends in the presence interannual variability, J. Geophys. Res., 118, 12257-12273, doi:10.1002/2013JD020258, 2013.
Turquety, S., Hurtmans, D., Hadji-Lazaro, J., Coheur, P.-F., Clerbaux, C., Josset, D., and Tsamalis, C.: Tracking the emission and transport of pollution from wildfires using the IASI CO retrievals: analysis of the summer 2007 Greek fires, Atmos. Chem. Phys., 9, 4897-4913, doi:10.5194/acp-9-4897-2009, 2009.

Wagner, A., Blechschmidt, A.-M., Bouarar, I., Brunke, E.-G., Clerbaux, C., Cupeiro, M., Cristofanelli, P., Eskes, H., Flemming, J., Flentje, H., George, M., Gilge, S., Hilboll, A., Inness, A., Kapsomenakis, J., Richter, A., Ries, L., Spangl, W., Stein, O., Weller, R., and Zerefos, C.: Evaluation of the MACC operational forecast system - potential and challenges of global near-real-time modelling with respect to reactive gases in the troposphere, Atmos. Chem. Phys. Discuss., 15, 6277-6335, doi:10.5194/acpd-15-6277-2015, 2015.

Warner, J., Comer, M. M., Barnet, C. D., McMillan, W. W., Wolf, W., Maddy, E., and Sachse, G.: A comparison of satellite tropospheric carbon monoxide measurements from AIRS and MOPITT during INTEX-A, J. Geophys. Res., 112, D12S17, doi:10.1029/2006JD007925, 2007.

Worden, H. M., Deeter, M. N., Frankenberg, C., George, M., Nichitiu, F., Worden, J., Aben, I., Bowman, K. W., Clerbaux, C., Coheur, P. F., de Laat, A. T. J., Detweiler, R., Drummond, J. R., Edwards, D. P., Gille, J. C., Hurtmans, D., Luo, M., MartínezAlonso, S., Massie, S., Pfister, G., and Warner, J. X.: Decadal record of satellite carbon monoxide observations, Atmos. Chem. Phys., 13, 837-850, doi:10.5194/acp-13-837-2013, 2013.

Yurganov, L. N., Rakitin, V., Dzhola, A., August, T., Fokeeva, E., George, M., Gorchakov, G., Grechko, E., Hannon, S., Karpov, A., Ott, L., Semutnikova, E., Shumsky, R., and Strow, L.: Satellite- and ground-based CO total column observations over 2010 Russian fires: accuracy of top-down estimates based on thermal IR satellite data, Atmos. Chem. Phys., 11, 7925-7942, doi:10.5194/acp-11-7925-2011, 2011.

Zhou, D. K., Larar, A. M., Liu, X., Smith, W. L., Strow, L. L., Yang, P., Schlussel, P., and Calbet, X.: Global land surface emissivity retrieved from satellite ultraspectral IR measurements, IEEE T. Geosci. Remote Sens., 49, 1277-1290, doi:10.1109/TGRS.2010.2051036, 2011. 